\title{
Wrangellia flood basalts in Alaska: A record of plume-lithosphere interaction in a Late Triassic accreted oceanic plateau
}

\author{
Andrew R. Greene, James S. Scoates, and Dominique Weis \\ Pacific Centre for Isotopic and Geochemical Research, Department of Earth and Ocean Sciences, University of British \\ Columbia, 6339 Stores Road, Vancouver, British Columbia V6T 1Z4, Canada (agreene@eos.ubc.ca)
}

[1] The Wrangellia flood basalts are part of one of the best exposed accreted oceanic plateaus on Earth. They provide important constraints on the construction of these vast submarine edifices and the source and temporal evolution of magmas for a plume head impinging beneath oceanic lithosphere. Wrangellia flood basalts ( 231-225 Ma) extend $\sim 450 \mathrm{~km}$ across southern Alaska (Wrangell Mountains and Alaska Range) where $\sim 3.5 \mathrm{~km}$ of mostly subaerial flows are bounded by late Paleozoic arc volcanics and Late Triassic limestone. The vast majority of the flood basalts are light rare earth element (LREE) -enriched high-Ti basalt $\left(1.6-2.4 \mathrm{wt} \% \mathrm{TiO}_{2}\right)$ with uniform ocean island basalt (OIB) -type Pacific mantle isotopic compositions $\left(\varepsilon_{\mathrm{Hf}}(\mathrm{t})=+9.7\right.$ to $+10.7 ; \varepsilon_{\mathrm{Nd}}(\mathrm{t})=+6.0$ to $\left.+8.1 ; \mathrm{t}=230 \mathrm{Ma}\right)$. However, the lowest $\sim 400 \mathrm{~m}$ of stratigraphy in the Alaska Range is LREE-depleted low-Ti basalt $\left(0.4-1.2 \mathrm{wt} \% \mathrm{TiO}_{2}\right)$ with pronounced negative high field strength element (HFSE) anomalies and Hf isotopic compositions $\left(\varepsilon_{\mathrm{Hf}}(\mathrm{t})=+13.7\right.$ to $+18.4)$ that are decoupled from $\mathrm{Nd}\left(\varepsilon_{\mathrm{Nd}}(\mathrm{t})=+4.6\right.$ to +5.4$)$ and displaced well above the OIB mantle array $\left(\Delta \varepsilon_{\mathrm{Hf}}=+4\right.$ to +8$)$. The radiogenic $\mathrm{Hf}$ of the low-Ti basalts indicates involvement of a component that evolved with high $\mathrm{Lu} / \mathrm{Hf}$ over time but not with a correspondingly high $\mathrm{Sm} / \mathrm{Nd}$. The radiogenic $\mathrm{Hf}$ and HFSE-depleted signature of the low-Ti basalts suggest pre-existing arc lithosphere was involved in the formation of flood basalts that erupted early in construction of part of the Wrangellia plateau in Alaska. Thermal and mechanical erosion of the base of the lithosphere by the impinging plume head may have led to melting of arc lithosphere or interaction of plume-derived melts and subduction-modified mantle. The high-Ti lavas dominate the main phase of construction of the plateau and were derived from a depleted mantle source distinct from the source of MORB and with compositional similarities to that of ocean islands (e.g., Hawaii) and plateaus (e.g., Ontong Java) in the Pacific Ocean.

Components: 18,987 words, 18 figures, 4 tables.

Keywords: Wrangellia; Nikolai Formation; Alaska; oceanic plateau; high-titanium basalt; low-titanium basalt.

Index Terms: 1033 Geochemistry: Intra-plate processes (3615, 8415); 1037 Geochemistry: Magma genesis and partial melting (3619); 1040 Geochemistry: Radiogenic isotope geochemistry.

Received 11 May 2008; Revised 23 September 2008; Accepted 3 October 2008; Published 4 December 2008.

Greene, A. R., J. S. Scoates, and D. Weis (2008), Wrangellia flood basalts in Alaska: A record of plume-lithosphere interaction in a Late Triassic accreted oceanic plateau, Geochem. Geophys. Geosyst., 9, Q12004, doi:10.1029/2008GC002092. 


\section{Introduction}

[2] Oceanic plateaus and continental flood basalts (CFBs) represent transient large igneous provinces (LIPs) that are produced from the largest mantle melting events recorded on Earth. Oceanic plateaus and CFBs form from unusually high magmatic fluxes during emplacement over several million years or less [Saunders, 2005]. A longstanding controversy concerning the origin of magmas in many transient LIPs worldwide is whether they form by melting of the lithospheric mantle during any stage of LIP emplacement. CFBs have compositions that indicate involvement of subcontinental lithospheric mantle [e.g., Peate and Hawkesworth, 1996]. Compositional evidence of involvement of the lithospheric mantle in lavas erupted in oceanic plateaus, however, remains elusive. Although Ocean Drilling Program (ODP) and Deep Sea Drilling Program (DSDP) legs have drilled extant oceanic plateaus in the ocean basins, the vast majority of the stratigraphic sequence of oceanic plateaus remains generally unsampled and undescribed. Oceanic plateaus are enormous volcanic edifices (2-4 km high above the ocean floor) that are isolated from continents and form upon mid-ocean ridges, extinct arcs, detached or submerged continental fragments, or in intraplate settings [Coffin et al., 2006]. The basalts that form oceanic plateaus have a better chance of avoiding interaction with continental lithosphere than basalts erupted along the margins or in the interiors of continents [Kerr and Mahoney, 2007].

[3] An enduring issue involving the geochemistry of flood basalt provinces has been the origin of high- and low-titanium basalts within the flood basalt stratigraphy [e.g., Arndt et al., 1993]. Numerous LIPs have been found to possess two or more distinguishable groups of basalts based on titanium contents (e.g., Siberia [Wooden et al., 1993]; Emeishan [Xu et al., 2001]; Central Atlantic Magmatic Province [Nomade et al., 2002]; Karoo [Cox et al., 1967]; Ferrar [Hornig, 1993]; ParanáEtendeka [Peate, 1997]; Deccan [Melluso et al., 1995]; Ethiopia [Pik et al., 1998]; Columbia River Basalts [Hooper and Hawkesworth, 1993]). In several of these provinces, the high- and lowtitanium basalts are geographically distributed within the province, and in several provinces these lava types have a distinct stratigraphic distribution. However, all of these LIPs formed upon continental crust and involved interaction with metasomatized lithospheric mantle or continental crust during parts of their eruptive histories.
[4] The Wrangellia flood basalts in Alaska are remnants of an oceanic plateau that erupted in the eastern Panthalassic Ocean over $<5 \mathrm{Ma}$ in the Middle to Late Triassic, with accretion to western North America occurring in the Late Jurassic or Early Cretaceous [Jones et al., 1977]. The Wrangellia flood basalts form thick successions of flood basalts bounded by marine sediments that extend over areas of Alaska, Yukon, and British Columbia $(>2300 \mathrm{~km}$ in length). In south central Alaska, the flood basalt stratigraphy overlies late Paleozoic oceanic arc crust and marine sediments and is overlain by Late Triassic limestone. Most of the 3.5-4 km-thick sequence of flood basalts in Alaska erupted subaerially; however, in areas of Alaska there are pillowed and volcaniclastic basalts in the lower part of the volcanic stratigraphy.

[5] The Wrangellia oceanic plateau in Alaska is unusual as it is part of one of the only known LIPs that was constructed on the volcanic sequences of an older island arc. This raises the possibility that the erupted basalts contain a component from the subarc lithospheric mantle of this late Paleozoic arc. This is an intriguing hypothesis to test since both high- and low-titanium basalts have been recognized in the volcanic stratigraphy in Alaska as a result of this study, and thus may provide a direct comparison to CFBs built on older continental lithosphere.

[6] This study examines the volcanic stratigraphy, petrography, and geochemistry of flood basalts in the Wrangell Mountains and Alaska Range in south central Alaska and assesses the nature of the source and the origin of high- and low-titanium basalts in this part of the accreted Wrangellia oceanic plateau. A mantle plume origin was proposed for Wrangellia flood basalts by Richards et al. [1991] based on the large volume of flood basalts erupted in a short duration, the absence of evidence of rifting, and evidence of uplift prior to eruption of the flood basalts. The only previous modern analytical study of the Wrangellia flood basalts in Alaska involved major and trace element chemistry, and $\mathrm{Sr}, \mathrm{Nd}$, and $\mathrm{Pb}$ isotopic analyses, of nine basalts from the Wrangell Mountains [Lassiter et al., 1995]. This present study is part of a larger research project on the origin and evolution of the Triassic Wrangellia flood basalts in Alaska, Yukon, and British Columbia [Greene et al., 2008a, 2008b]. These areas (each $\sim 400 \mathrm{~km}$ in length, for a total length of $\sim 2300 \mathrm{~km}$ ) have different volcanic stratigraphy, distinct geochemical characteristics (and similarities), and they overlie Paleo- 


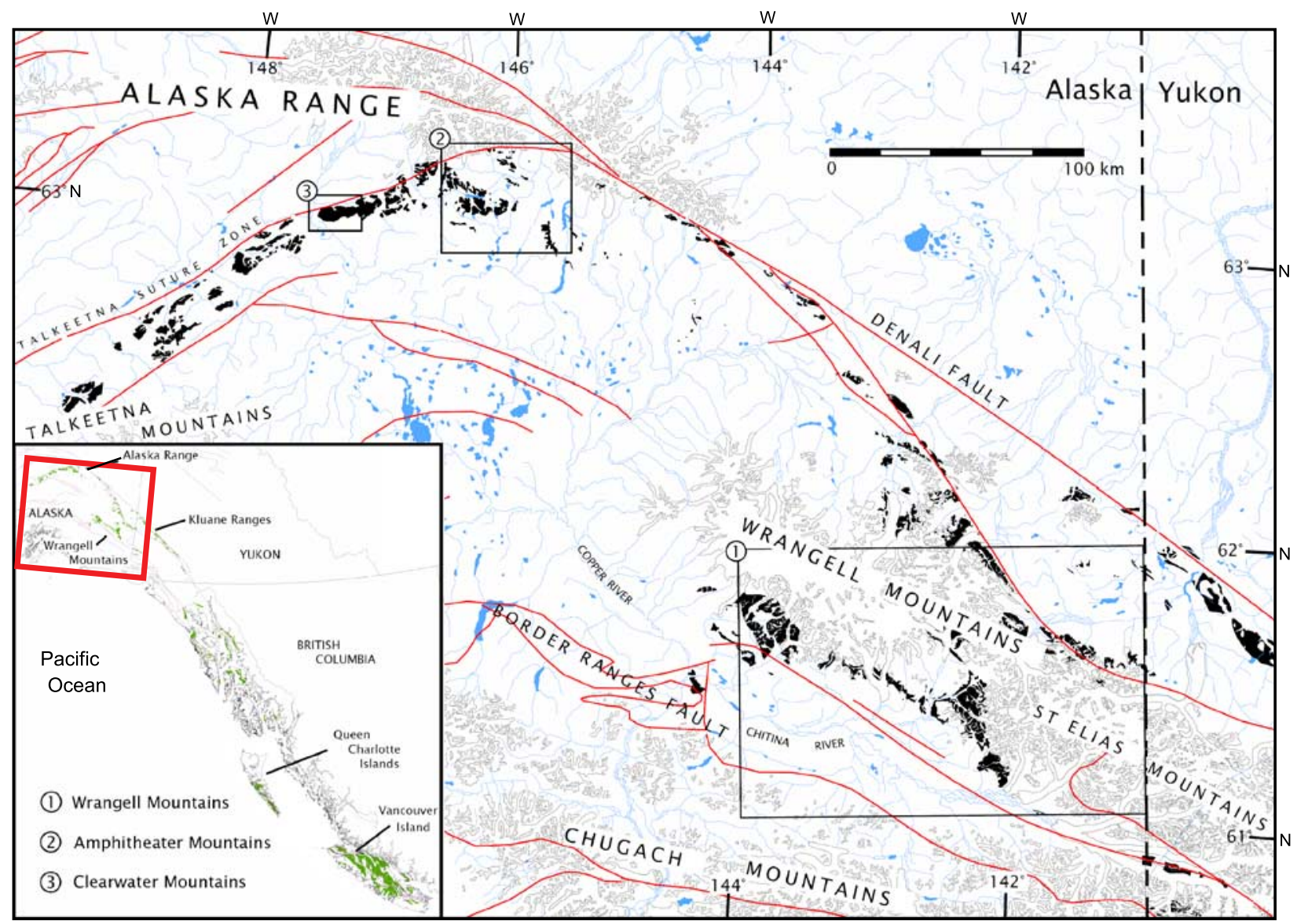

Figure 1. Simplified map of south-central Alaska showing the distribution of the Nikolai Formation (black), derived from the GIS-based digital map compilations of Wilson et al. [1998, 2005] and J. M. Schmidt (personal communication, 2006). The three main areas that were studied are outlined with boxes and indicated in the legend. The inset shows the extent of the Wrangellia flood basalts (green) in Alaska, Yukon, and British Columbia, with a red box indicating the map location. The red lines are faults and gray lines are glaciers.

zoic basement of different age and lithology. Exploring the internal stratigraphy and geochemistry of the accreted Wrangellia oceanic plateau provides constraints on the composition of less accessible examples in the ocean basins such as the Ontong Java and Kerguelen Plateaus.

\section{Geologic Setting}

\subsection{Wrangellia in Alaska}

[7] The Wrangellia Terrane, or Wrangellia, was defined by Jones et al. [1977] as a set of faultbound crustal blocks with similar-aged flood basalts overlain by limestone along the margin of western North America (Figure 1). The Wrangellia flood basalts have been mapped as the Nikolai Formation in Alaska and Yukon where they directly overlie shale with Middle to Late Ladinian ( 235-
$232 \mathrm{Ma}$ Daonella. Wrangellia may have joined with parts of the Alexander Terrane, primarily in southeast Alaska, as early as the Late Pennsylvanian [Gardner et al., 1988] and may have been in close proximity to the Peninsular Terrane of southern Alaska by the Late Triassic [Rioux et al., 2007].

[8] Wrangellia extends $\sim 450 \mathrm{~km}$ in an arcuate belt across southern Alaska in the Wrangell Mountains, Alaska Range, and Talkeetna Mountains (Figure 1). The northwest margin of Wrangellia is one of the most prominent geophysical features in south central Alaska and is exposed along the Talkeetna Suture Zone [Glen et al., 2007]. The suture between Wrangellia and transitional crust to the northwest is well-defined geophysically [Glen et al., 2007] and lies directly in the axis of the major orocline of southern Alaska, where structures curve from northwest- to northeast-trending [e.g., Plafker 


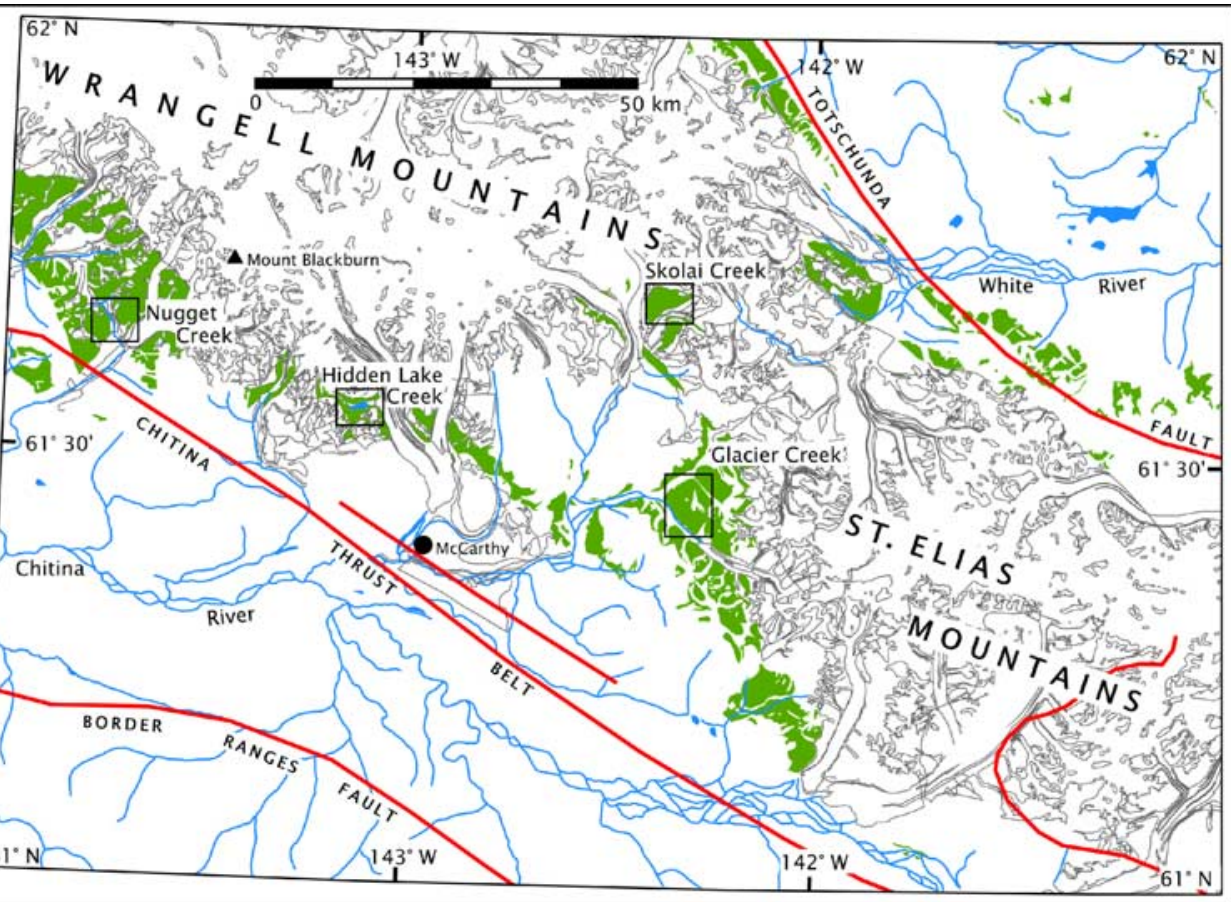

Figure 2. Geologic map and stratigraphy of the Wrangell Mountains, Alaska (map location shown by box 1 in Figure 1). (a) Stratigraphic column depicts late Paleozoic to Jurassic units on the south side of the Wrangell Mountains, derived from Smith and MacKevett [1970] and MacKevett [1978]. (b) Simplified map showing the distribution of the Nikolai Formation (green) in the Wrangell Mountains, derived from the GIS-based digital map compilation of Wilson et al. [2005]. The four areas of field study are outlined with labeled boxes. The red lines are faults, gray lines are glaciers, and blue lines are rivers.

et al., 1994]. Wrangellia is bounded by the Denali Fault to the northeast and extends more than $300 \mathrm{~km}$ to the southeast in Yukon.

\subsubsection{Wrangell Mountains}

[9] Wrangellia stratigraphy is well-exposed in a northwest-trending belt extending $\sim 100 \mathrm{~km}$ along the southern flank of the Wrangell Mountains in Wrangell-St. Elias National Park (Figure 2). The Nikolai Formation unconformably overlies the Skolai Group, which comprises Pennsylvanian to Early Permian volcanic arc sequences and marine sediments of the Station Creek and Hasen Creek Formations, respectively [Smith and MacKevett, 1970; Figure 2]. The Skolai Group is intruded by mafic and ultramafic intrusive bodies related to the Nikolai basalts. Exposures of the Nikolai basalts cover $\sim 1057 \mathrm{~km}^{2}$ in Wrangell-St. Elias National Park and are approximately $3.5-4 \mathrm{~km}$ in total thickness. Over $3.5 \mathrm{~km}$ of marine sedimentary rocks, ranging in age from Late Triassic to Late Jurassic, overlie the Nikolai Formation in the Wrangell Mountains [MacKevett et al., 1997], and in turn are overlain by Cretaceous sedimentary sequences and the Miocene to Holocene Wrangell volcanics [MacKevett, 1978; Richter et al., 1990].

\subsubsection{Eastern Alaska Range}

[10] The Nikolai Formation in the eastern Alaska Range and small areas of the Talkeetna Mountains is exposed over $\sim 666 \mathrm{~km}^{2}$ and is $3.5-4 \mathrm{~km}$ thick in the Amphitheater and Clearwater Mountains (Figure 1). Volcanic and marine sedimentary sequences similar to the late Paleozoic successions in the Wrangell Mountains underlie the Nikolai basalts in the Alaska Range [Nokleberg et al., 1994]. The most significant occurrence of plutonic rocks associated with the Nikolai basalts occurs in the Amphitheater Mountains within a broad synform. Sequences overlying the Nikolai basalts are poorly exposed in the Amphitheater Mountains but preserve interbedded volcanic and sedimentary horizons that give way to fine-grained marine sedimentary strata.

\subsection{Age of the Nikolai Formation}

[11] Biostratigraphy and geochronology provide bounds on the age and duration of emplacement of the Nikolai basalts. Fossil assemblages in finely 

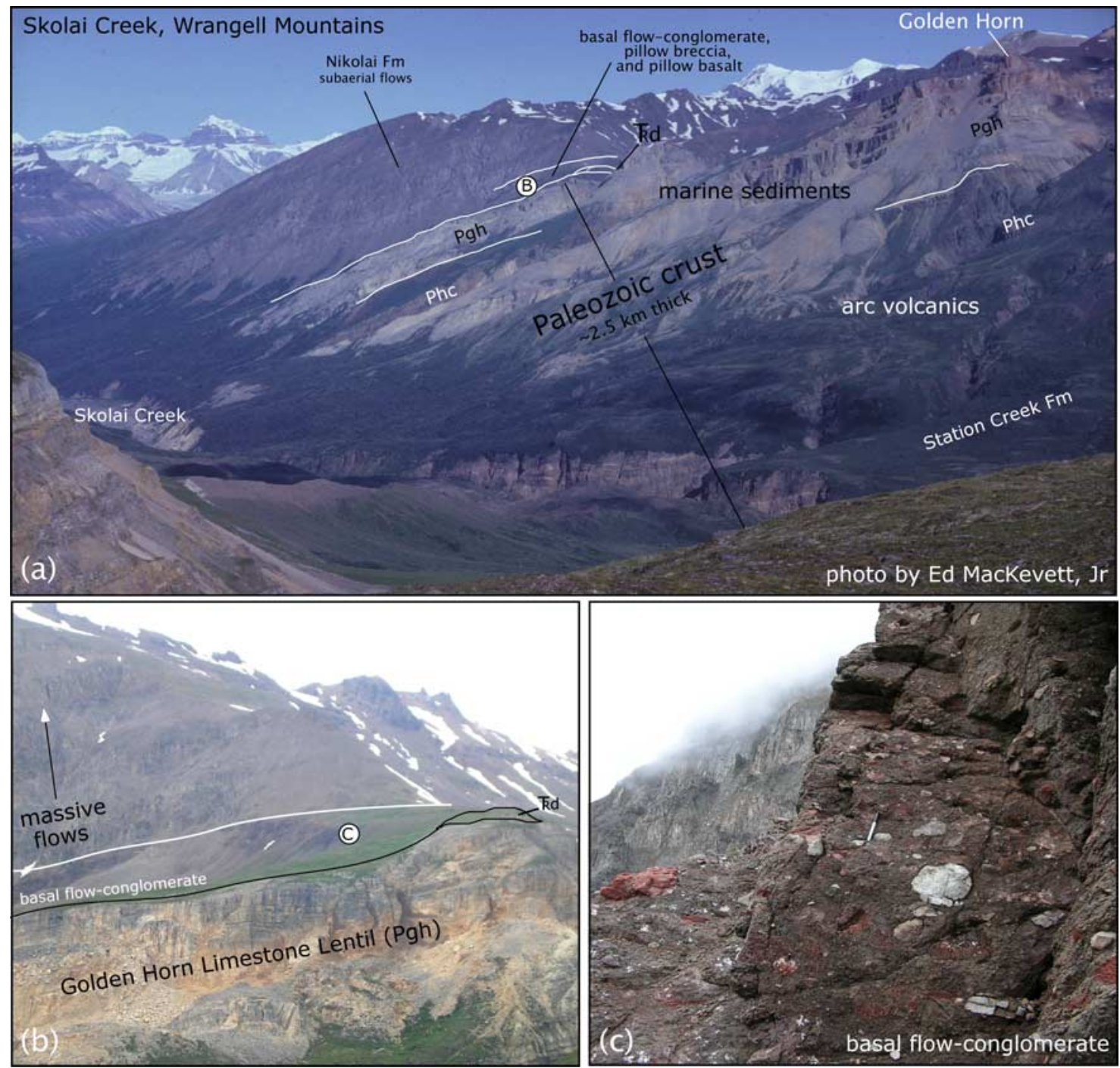

Figure 3. Photographs of the base of the Nikolai Formation in the Wrangell Mountains, Alaska. (a) Westward dipping Paleozoic arc volcanic rocks of the Station Creek Formation overlain by Early Permian shale and limestone (Phc-Hasen Creek Formation; Pgh-Golden Horn Limestone Lentil), isolated lenses of Middle Triassic "Daonella beds" (TRd), basalt flow-conglomerate with local pillows, and massive subaerial flows on the north side of Skolai Creek. Photograph by Ed MacKevett Jr. (b) Close-up photograph of area b in Figure 3a. (c) Close-up photograph of area $\mathrm{c}$ in Figure $3 \mathrm{~b}$ showing basal flow-conglomerate with clasts of rounded cobbles of white limestone $(<20 \mathrm{~cm})$ derived from Golden Horn Limestone Lentil and red basalt $(<40 \mathrm{~cm})$ from Station Creek Formation. Pen $(14 \mathrm{~cm})$ in middle of photograph for scale.

laminated shale immediately beneath the Nikolai basalts in the Wrangell Mountains indicate a Middle to Late Ladinian age ( 235-232 Ma) [Jones et al., 1977; C. A. McRoberts, personal communication, 2007] and fossils in limestone disconformably overlying the Nikolai Formation are Late Carnian to Early Norian ( 223-212 Ma) [Armstrong and MacKevett, 1977; Plafker et al., 1989]. Five ${ }^{40} \mathrm{Ar} /{ }^{\beta 9} \mathrm{Ar}$ plateau ages for hornblende and biotite from intrusive rocks in the Amphitheater Mountains in the Alaska Range, which are interpreted to be comagmatic with Nikolai basalts, indicate for- mation of these rocks at $\sim 231-225 \mathrm{Ma}$ [Bittenbender et al., 2007; Schmidt and Rogers, 2007]. Three Nikolai basalt samples from the Wrangell Mountains yielded ${ }^{40} \mathrm{Ar} /{ }^{39} \mathrm{Ar}$ step-heating ages of $228.3 \pm 5.2,232.8 \pm 11.5$, and $232.4 \pm$ 11.9 Ma [Lassiter, 1995].

\section{Volcanic Stratigraphy}

[12] Field studies in Alaska focused in three general areas where parts of the entire flood basalt 


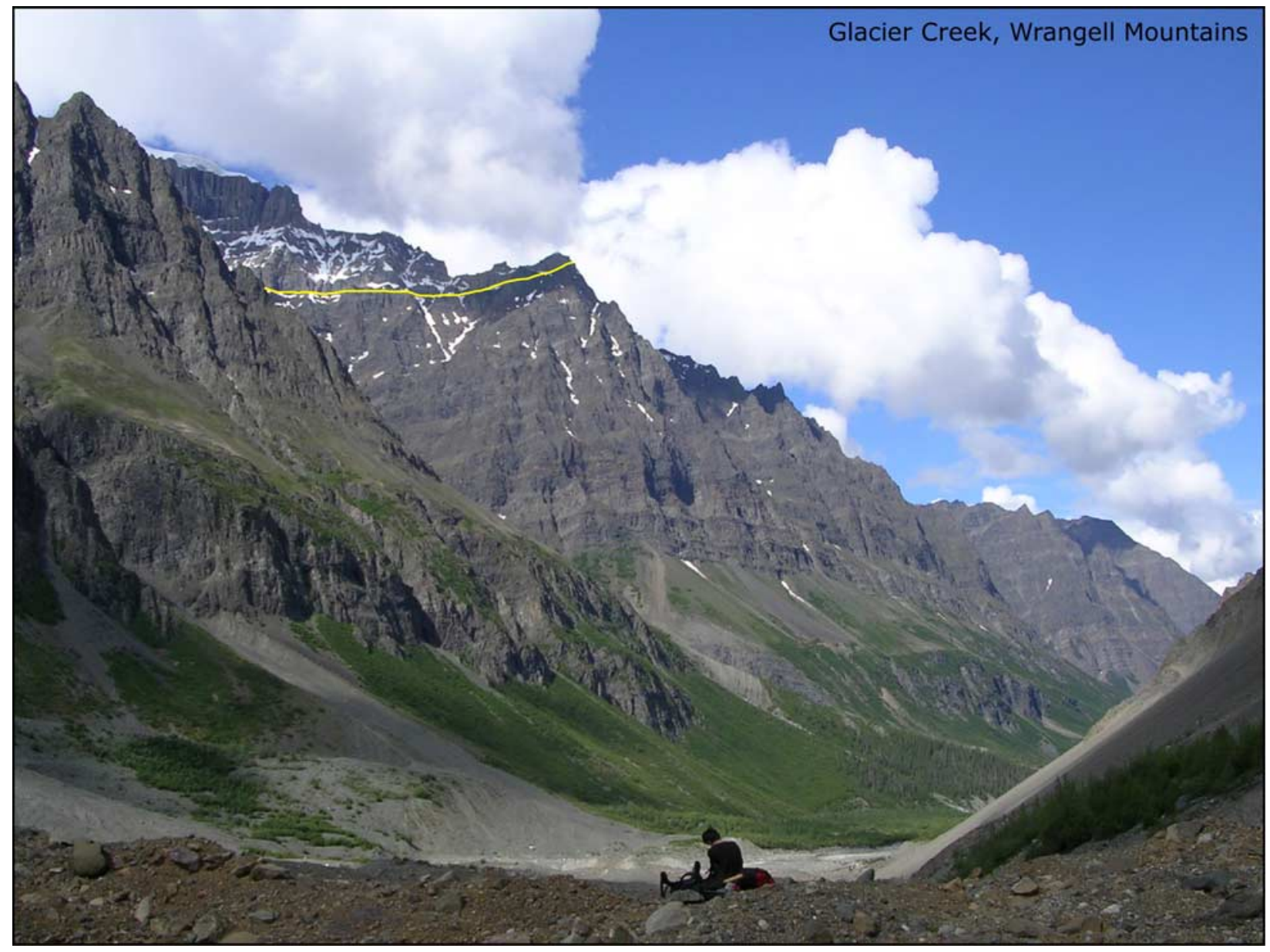

Figure 4. Photograph of $\sim 1000 \mathrm{~m}$ of continuous subaerial flood basalt stratigraphy at the top of the Nikolai Formation along Glacier Creek in the Wrangell Mountains, Alaska. The yellow line marks the contact between Nikolai basalts and the overlying Chitistone Limestone.

stratigraphy are well exposed: the southern flank of the Wrangell Mountains and the Amphitheater and Clearwater Mountains in the southern part of the eastern Alaska Range (Figure 1).

[13] In the Wrangell Mountains, four areas were examined and sampled: Skolai Creek, Glacier Creek, Hidden Lake Creek, and Nugget Creek (Figure 2). The volcanic stratigraphy in the Wrangell Mountains is predominantly subaerial flows with $<100 \mathrm{~m}$ of submarine flows along the base. The base of the Nikolai Formation is exposed at Skolai Creek where basalt flow-conglomerate, pillow breccia, and minor pillow basalt unconformably overlie the Paleozoic Sicker Group (Figures 2 and 3). Middle to upper portions of the flood basalt stratigraphy are well exposed above Glacier Creek, where massive maroon- and green-colored flows form monotonous sequences with amygdaloidal- rich horizons and no discernible erosional surfaces or sediments between flows (Figure 4). The top of the flood basalts are best exposed around Hidden Lake Creek where a sharp contact between Nikolai basalts and overlying Chitistone Limestone is mostly a smooth surface with minimal evidence of weathering [Armstrong and MacKevett, 1982] (Figure 5 ).

[14] In the Amphitheater Mountains, fieldwork was concentrated in five areas: Glacier Gap Lake, Landmark Gap Lake, Tangle Lakes (West), Sugarloaf Mountain, and Rainy Creek (Figure 6). The Amphitheater Mountains south of the Eureka Creek Fault form a broad synform consisting of flood basalts $(3.5 \mathrm{~km}$ thick) with basal sill complexes and associated mafic and ultramafic rocks exposed along the outer margins. The lower $\sim 500 \mathrm{~m}$ of volcanic stratigraphy are submarine 

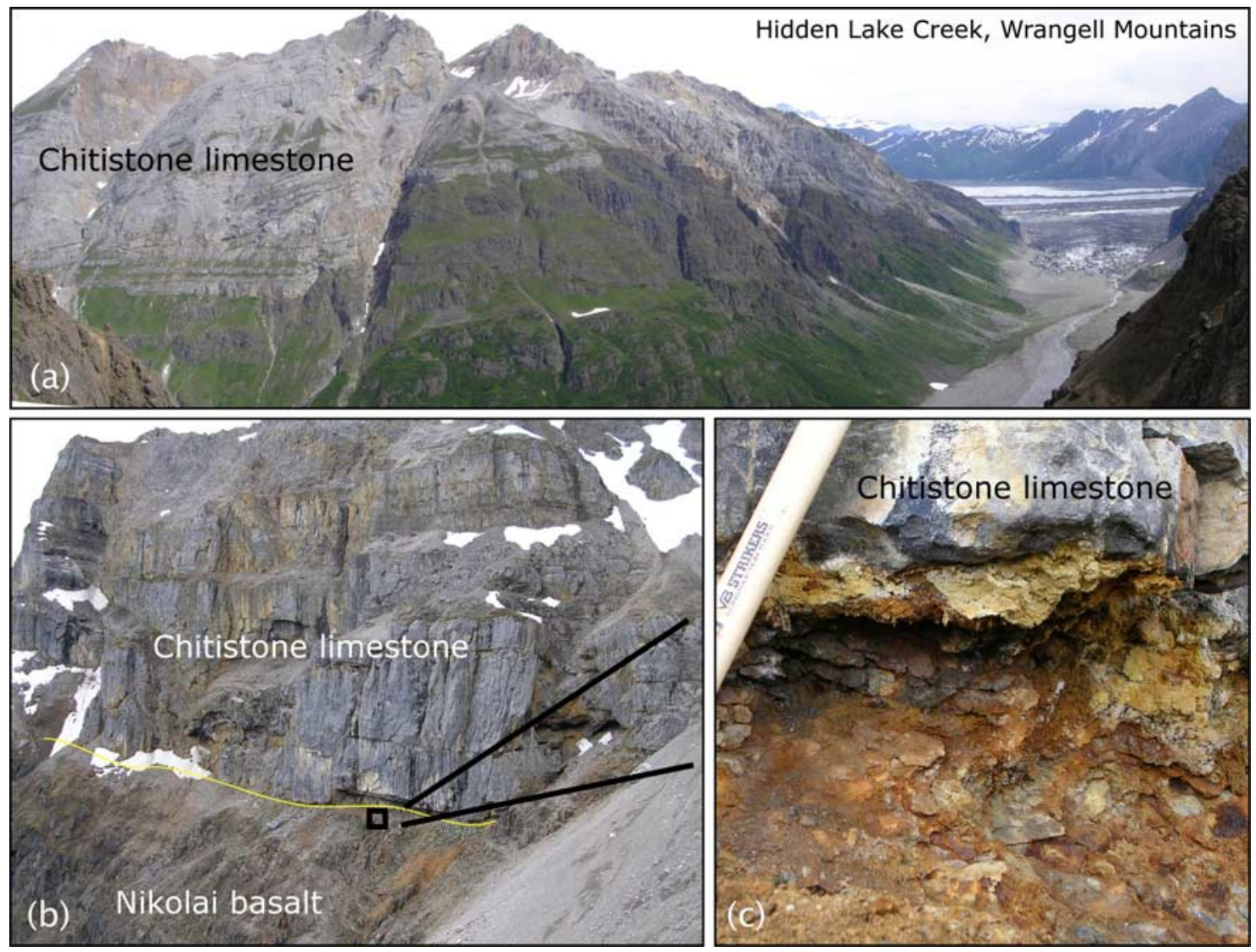

Figure 5. Photographs showing the top of the Nikolai Formation in the Wrangell Mountains, Alaska. (a) Chitistone Limestone overlying the Nikolai Formation above Hidden Creek in the Wrangell Mountains. Faulting has offset the contact. (b) Close-up photograph of uppermost Nikolai flow and base of the Chitistone Limestone from where Figure 5a was taken. (c) Cobbles $<10 \mathrm{~cm}$ long along the contact between the Chitistone Limestone and Nikolai Formation. The oxidized cobbles are subangular, closely packed, aligned along their long axes, and are glomeroporphyritic basalt identical to the uppermost flows of the Nikolai Formation. Sledgehammer handle (4 cm wide) for scale. Thinly bedded siltstone also occurs along the contact.

flows and the stratigraphy above this is mostly massive subaerial flows ( $<15 \mathrm{~m}$ thick). The lowest part of $\sim 1000 \mathrm{~m}$ of sills and submarine flows (e.g., Lower Tangle Lakes) consists of nonfossiliferous shale and siliceous argillite $(<4 \mathrm{~m}$ thick) interbedded with massive mafic sills (2-30 m thick), in turn overlain by pillow basalt (Figure 7). Sills interbedded with thinly bedded basaltic sandstone and minor hyaloclastite also occur higher in the submarine stratigraphy (Figures 6 and 7).

[15] A small segment of Wrangellia in the northern part of the Amphitheater Mountains consists of a heterogeneous assemblage of mafic and ultramafic plutonic and volcanic rocks that forms a wedge between the Broxson Gulch Thrust and the Eureka Creek Fault (Figure 6). These units are distinct from those within the synform and therefore a suite of eight samples, including several altered olivinebearing picritic tuffs (Rainy Creek picrites), were collected for comparison to Nikolai basalts within the synform.

[16] In the Clearwater Mountains ( $\sim 40 \mathrm{~km}$ west of the Amphitheater Mountains), the lower $<400 \mathrm{~m}$ of the volcanic stratigraphy is submarine flows and the remainder of the stratigraphy is primarily subaerial flows (see Auxiliary Material). ${ }^{1}$ The lowest flows are pillow basalt that directly overlie thin beds of shale and argillite $(<3 \mathrm{~m}$ thick). Picritic pillow lavas have been found in the submarine stratigraphy. The upper parts of the volcanic stratigraphy contain subaerial flows (or

${ }^{1}$ Auxiliary materials are available in the HTML. doi:10.1029/ 2008GC002092. 


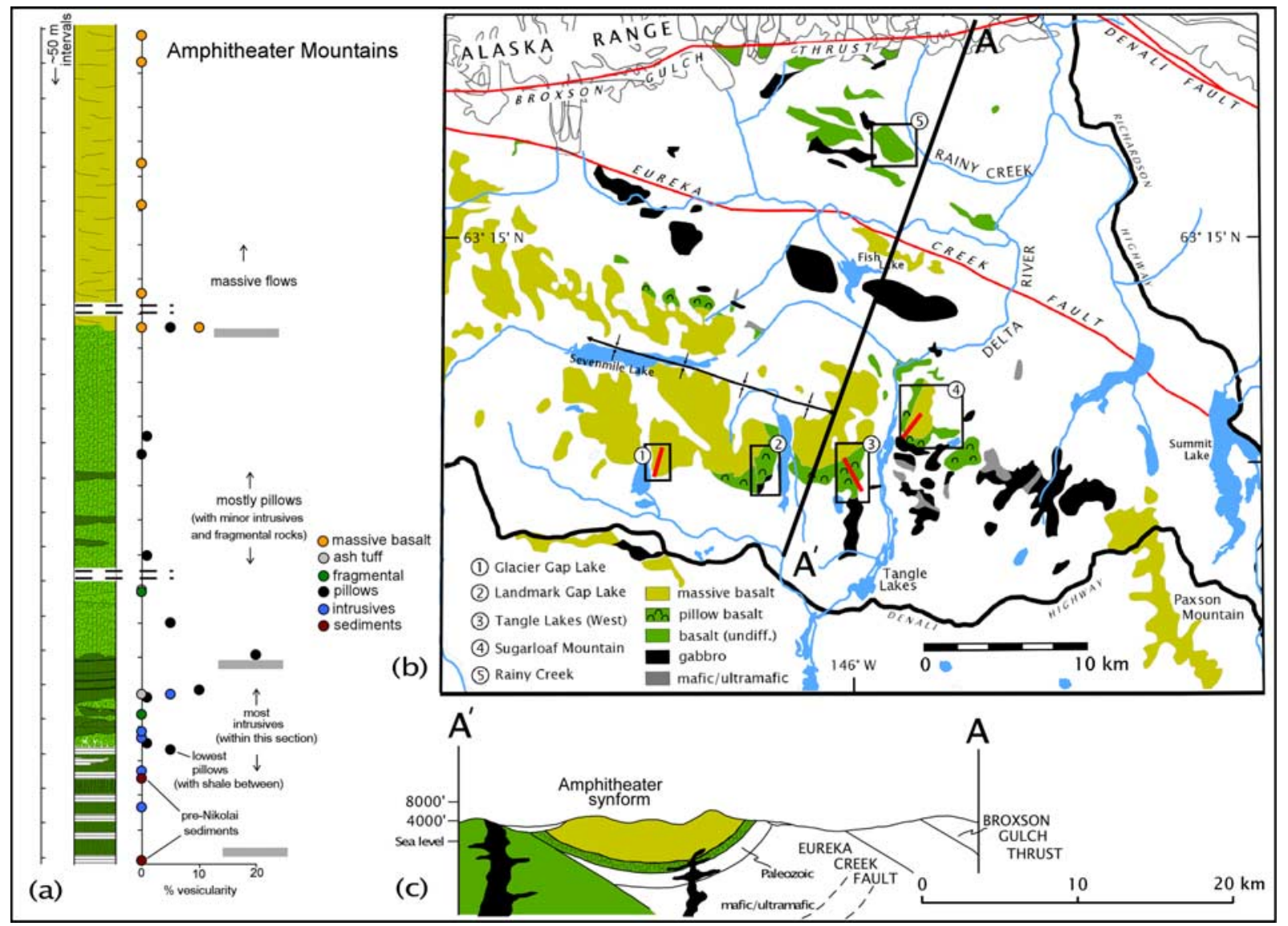

Figure 6. Simplified geologic map and stratigraphy of the Amphitheater Mountains, Alaska (map location shown by box 2 in Figure 1). (a) Stratigraphic column with sample lithologies and estimated vesicularity for flood basalts from the lower part of the volcanic stratigraphy, derived from three traverses marked by red lines in Figure $6 \mathrm{~b}$. Vesicularity estimated visually from thin-sections. (b) Generalized geology of the Nikolai Formation and related plutonic rocks in the Amphitheater Mountains. Five main field areas are outlined with numbered boxes (see legend). Map derived from Nokleberg et al. [1992] and the digital compilation of Wilson et al. [1998]. (c) Schematic crosssection of Amphitheater Mountains from A to A' in Figure 6b, adapted from Nokleberg et al. [1985].

sills) with columnar jointing, minor occurrences of tuff and volcanic breccia, and limestone and argillite lenses interbedded with flows are overlain by fine-grained sediments with diagnostic index fossils (bivalve Halobia and ammonoid Tropites [Smith, 1981]).

[17] A total of 111 samples of the Nikolai Formation and several Paleozoic, late Mesozoic, and Cenozoic volcanic and sedimentary rocks were collected for petrography and geochemical analysis. Fifty-three of these samples were selected for geochemistry based on the visual degree of alteration (see Auxiliary Material) and are grouped into high- and low-titanium basalts, sills, and picrites based on geochemistry. The sample preparation and analytical methods for whole-rock chemistry, major elements, trace elements, and $\mathrm{Sr}, \mathrm{Nd}, \mathrm{Hf}$, and $\mathrm{Pb}$ isotopes are described in Appendix A.

\section{Whole-Rock Chemistry}

\subsection{Major and Trace Element Compositions}

[18] The most noteworthy feature of the major element chemistry of the Nikolai Formation is two clearly distinguishable groups of high- and low-titanium basalt (Figure 8). The low-titanium basalts range from 0.4 to $1.2 \mathrm{wt} \% \mathrm{TiO}_{2}$ and the high-titanium basalts range from 1.6 to $2.4 \mathrm{wt} \%$ $\mathrm{TiO}_{2}$ (Figure 8; Table 1). The high-titanium basalts have a limited range in $\mathrm{MgO}(5.7-7.9$ wt \% $\mathrm{MgO}$, except for one plagioclase-rich flow with $4.8 \mathrm{wt} \%$ 

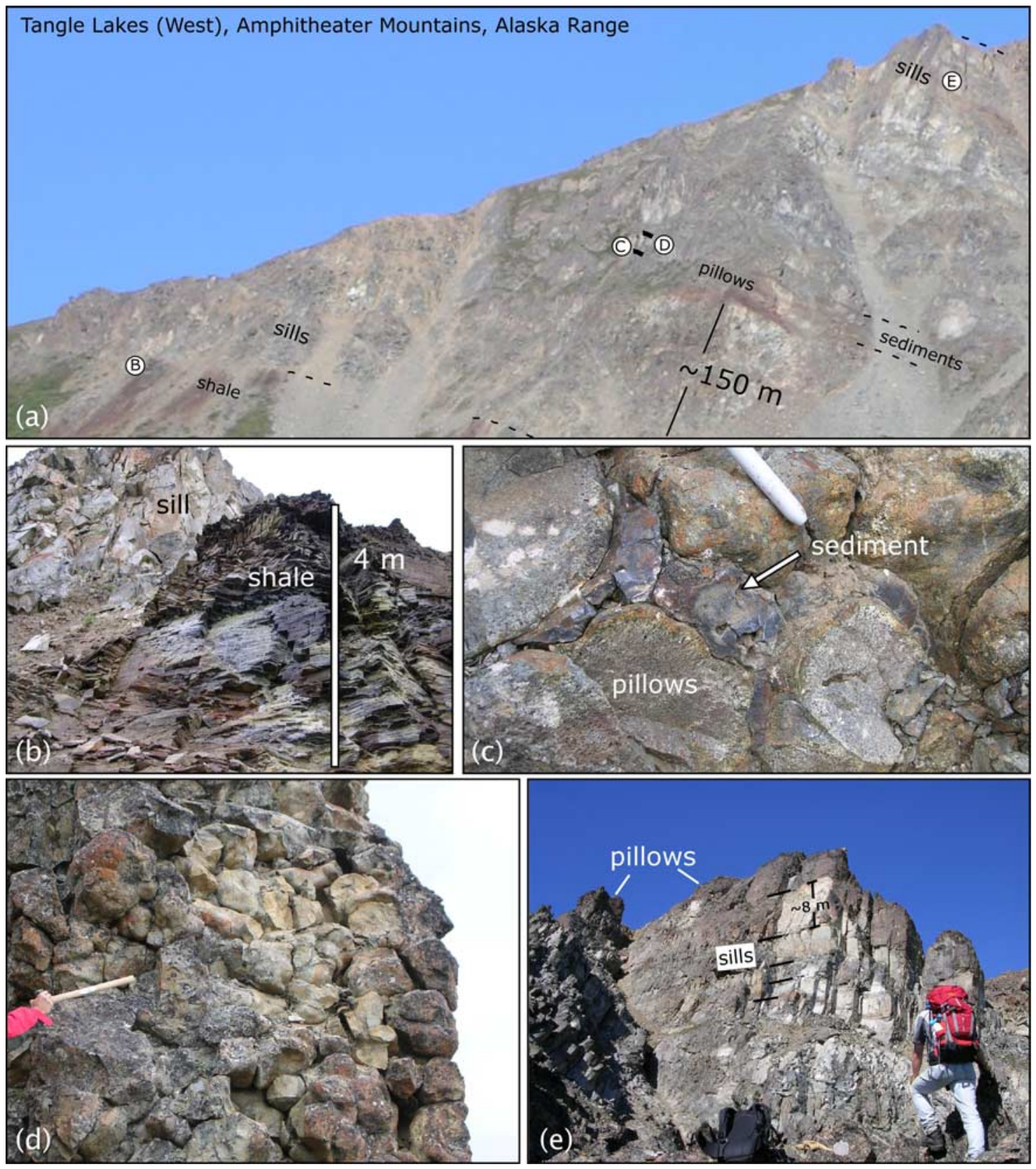

Figure 7. Photographs of the base of the Nikolai Formation in the Amphitheater Mountains, east central Alaska Range, Alaska (from the Tangle Lakes (West) area shown in Figure 6). (a) Basal sills and sediments beneath submarine flows. Letters denote locations of other photographs. (b) Fissile shale ( $\sim \mathrm{m}$ thick) and a mafic sill from the lowermost exposure of shale. (c) Pillow basalt with shale between pillows lying directly above shale similar to Figure 7b. (d) Pillow basalt (pillow tubes are $<1 \mathrm{~m}$ diameter in cross-section) in the lowermost flow (13 $\mathrm{m}$ thick) in the Tangle section. Figure $7 \mathrm{c}$ is from the base of this flow. Sledgehammer $(80 \mathrm{~cm}$ long $)$ for scale. (e) Sequence of at least four massive sills $(<8 \mathrm{~m}$ thick) interbedded with fine-grained tuff $(<2 \mathrm{~m}$ thick). Tuff layers interbedded with sills contain plagioclase crystals $(<0.5 \mathrm{~mm})$, curvilinear shards, and local areas of volcanic breccia containing basaltic clasts with abundant small acicular plagioclase $(<0.5 \mathrm{~mm})$.

$\mathrm{MgO})$ and $\mathrm{SiO}_{2}(49.2-52.1$ wt \%), whereas the low-titanium basalts extend to higher $\mathrm{MgO}$ and have a significantly larger range in $\mathrm{MgO}(6.4-$ 12.0 wt \%) and $\mathrm{SiO}_{2}(46.7-52.2$ wt \%). The low- titanium basalts have noticeably higher $\mathrm{Mg} \#$

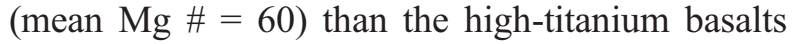
(mean $\mathrm{Mg} \#=50 ; \mathrm{Mg} \#=$ molar $\mathrm{MgO} /(\mathrm{MgO}+$ $\left.\mathrm{FeO}_{\mathrm{T}}\right) \times 100$, where $\mathrm{FeO}_{\mathrm{T}}$ refers to all $\mathrm{Fe}$ expressed 

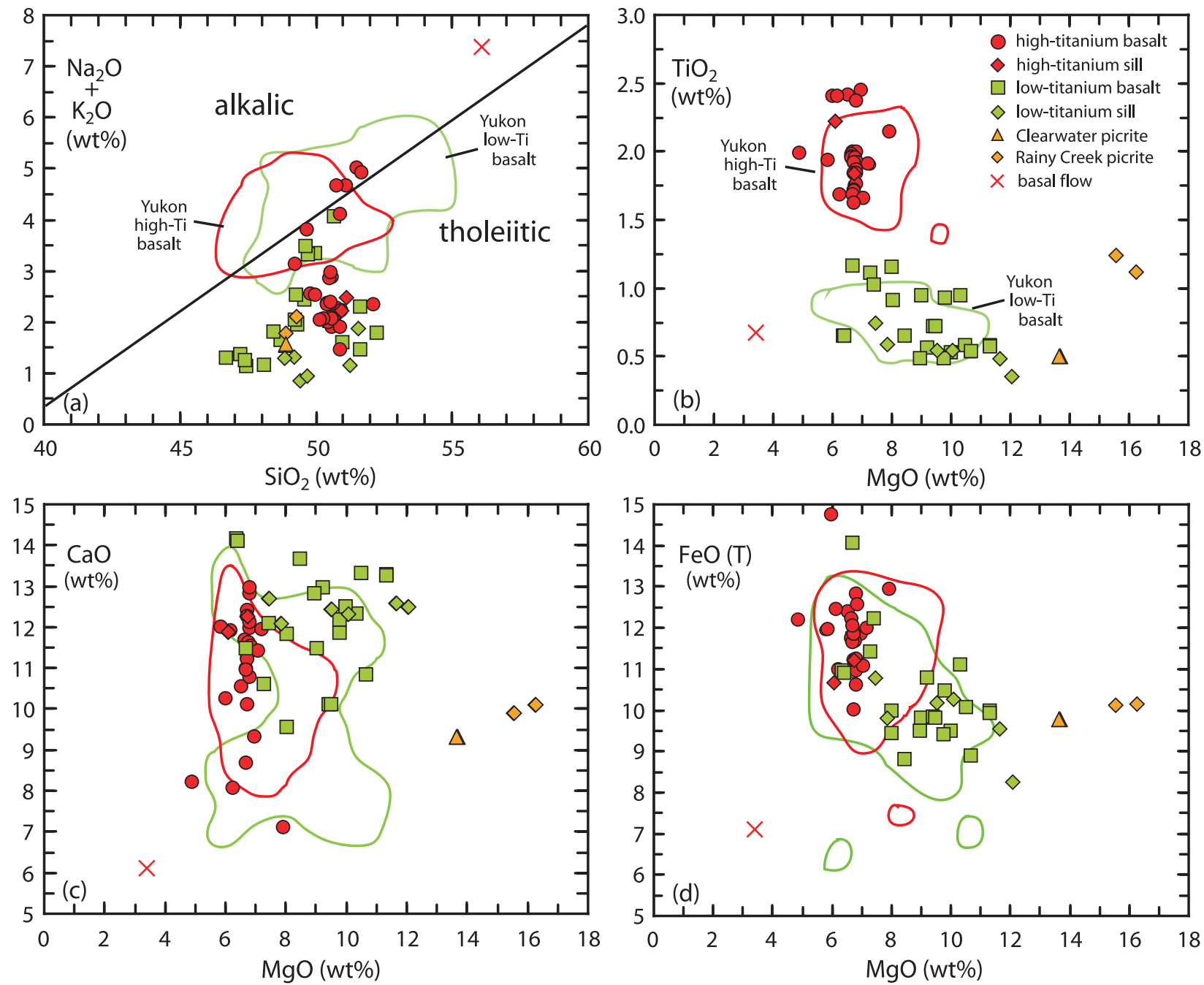

Figure 8. Whole-rock major element variation diagrams versus $\mathrm{MgO}$ for the Nikolai Formation in Alaska with fields for the Nikolai Formation in Yukon [Greene et al., 2008a]. The boundary of the alkalic and tholeiitic fields is that of MacDonald and Katsura [1964]. Total iron expressed as $\mathrm{FeO}$ and oxides are plotted on an anhydrous, normalized basis. Note the clear distinction between the high- and low-titanium basalts in Figure $8 \mathrm{~b}$ and the difference in alkali contents between the Nikolai basalts in Alaska and Yukon in Figure 8a. Fields for Nikolai basalts in Yukon are green for low-Ti basalts and red for high-Ti basalts.

as FeO). Nearly all of the Nikolai basalts in Alaska fall within the tholeiitic field in a total alkalis versus silica plot, with low-titanium basalts generally having lower total alkalis than the high-titanium basalts. The low-titanium basalts exhibit broadly decreasing trends of $\mathrm{TiO}_{2}, \mathrm{FeO}_{\mathrm{T}}$, and $\mathrm{Na}_{2} \mathrm{O}$ with increasing $\mathrm{MgO}$ (Figure 8) and have higher loss-onignition (LOI; mean LOI $=2.7 \pm 1.3 \mathrm{wt} \%$ ) than the high-titanium basalts (mean LOI $=1.9 \pm 1.5 \mathrm{wt} \%$; Table 1). Low-titanium basalts with $>8 \mathrm{wt} \% \mathrm{MgO}$ have higher concentrations of $\mathrm{Ni}$ than the hightitanium basalts and the three picrite samples have noticeably higher $\mathrm{Ni}$ concentrations (525$620 \mathrm{ppm}$ ) than all basalts. Both the high- and low-titanium basalts have a large range in $\mathrm{CaO}$, which appears to be independent of $\mathrm{MgO}$ variation. A single Clearwater picrite $(13.6 \mathrm{wt} \% \mathrm{MgO})$ and two Rainy Creek picrites (15.5-16.2 wt \% MgO) have higher $\mathrm{MgO}$ with similar $\mathrm{TiO}_{2}, \mathrm{FeO}_{\mathrm{T}}$, and alkali contents to the low-titanium basalts, however, the Rainy Creek picrites have lower $\mathrm{Al}_{2} \mathrm{O}_{3}$. The basal flow-conglomerate from the Wrangell Mountains has distinct major element chemistry compared to the other Nikolai basalts. Nikolai basalts in Alaska are lower in total alkalis than basalts from Yukon due to alkali metasomatism during alteration of the Yukon basalts [Greene et al., 2008a]. 
Table 1 (Sample). Major Element and Trace Element Abundances in Whole-Rock Samples of Nikolai Basalts, Alaska $^{\mathrm{a}}$ [The full Table 1 is available in the HTML version of this article at http://www.g-cubed.org]

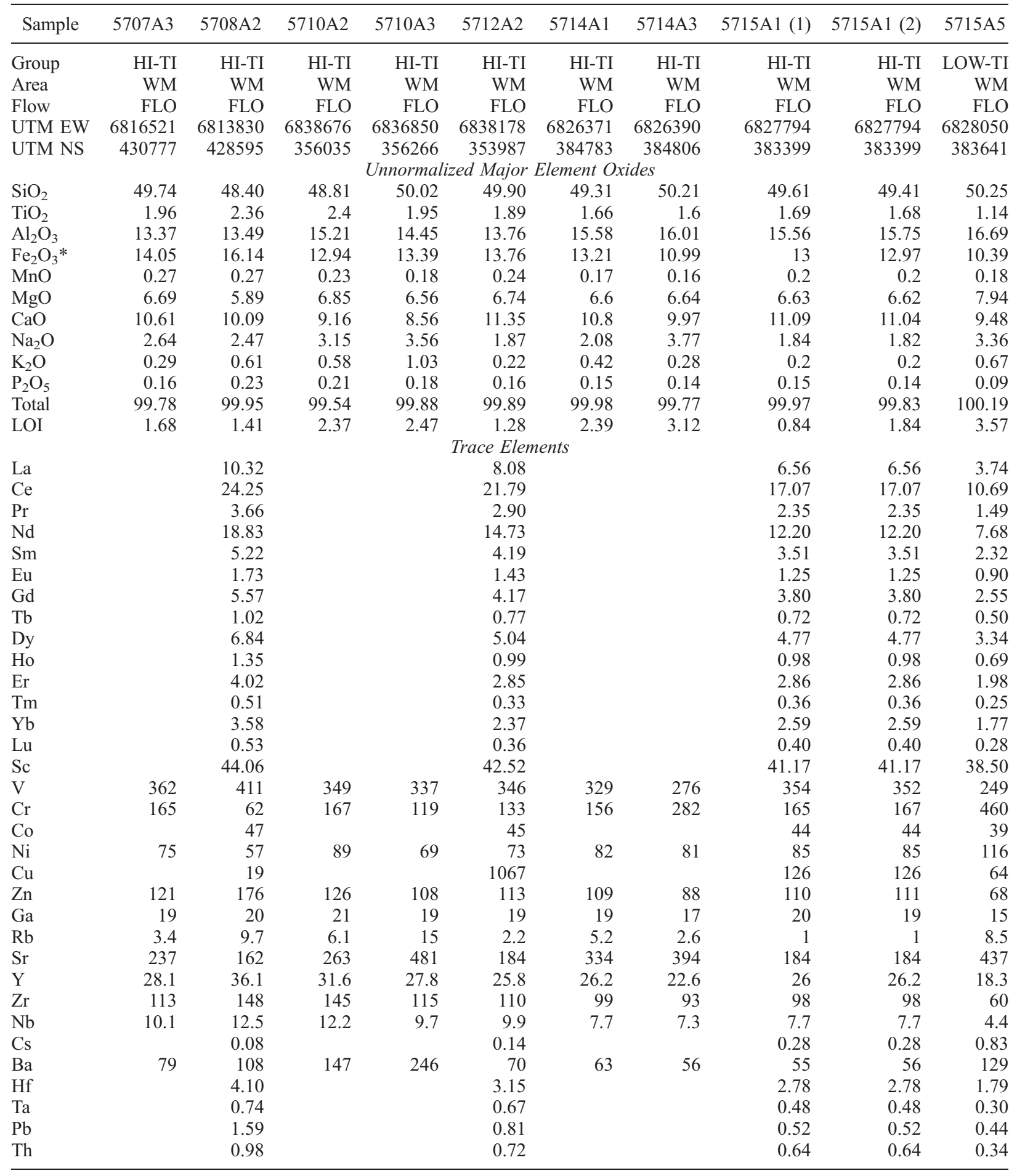

${ }^{\mathrm{a}}$ Major elements are measured in wt\% oxide and trace elements are measured in ppm. Abbreviations for group are HI-TI, high-titanium; LOWTI, low-titanium; RC, Rainy Creek; RCPIC, Rainy Creek picrite; CWPIC, Clearwater picrite. Abbreviations for flow are: FLO, massive flow; PIL, pillow basalt; FLO-BRE, flow-conglomerate-pillow breccia; SIL, sill; TUF, tuff. Abbreviations for area are: WM, Wrangell Mountains; TANGLE, Tangle Lakes; GLAC, Glacier Gap Lake; CLEAR, Clearwater Mountains; RAINY, Rainy Creek. Sample locations are given using the Universal Transverse Mercator (UTM) coordinate system (NAD83; zones 6 and 7). XRF analyses were performed at University of Massachusetts Ronald B. Gilmore XRF Laboratory. $\mathrm{Fe}_{2} \mathrm{O}_{3}$ * is total iron expressed as $\mathrm{Fe}_{2} \mathrm{O}_{3}$. LOI is loss-on-ignition. Totals have not been resummed using the LOI value. Elements by XRF: Sc, V, Cr, Ni, Zn, Ga, Rb, Sr, Y, Zr, Nb, Ba. Elements by ICP-MS: REE, Co, Cu, Cs, Hf, Ta, Pb, Th, U. 

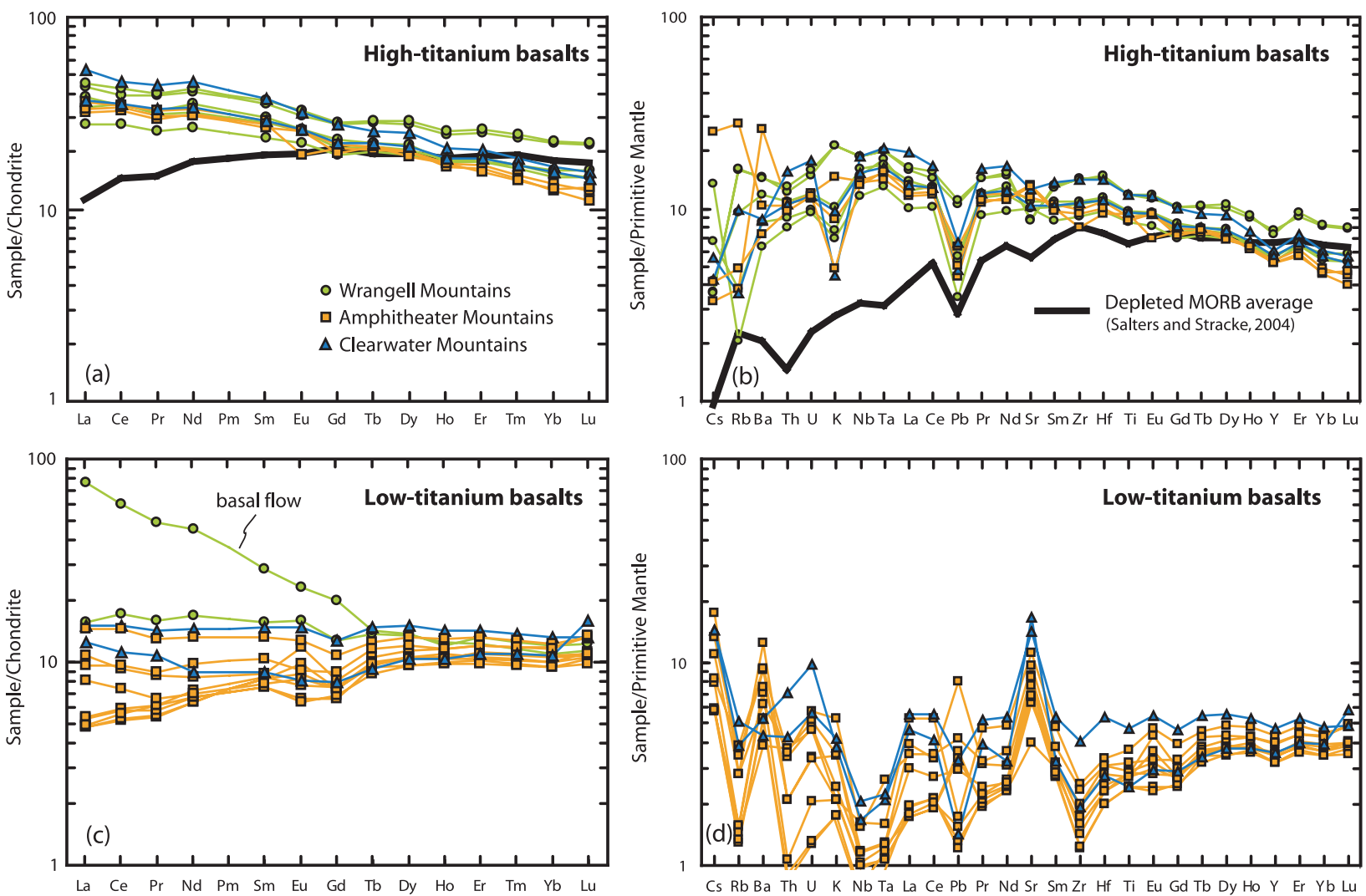

Cs Rb Ba Th U K Nb Ta La Ce Pb Pr Nd Sr Sm Zr Hf Ti Eu Gd Tb Dy Ho Y Er Yb Lu
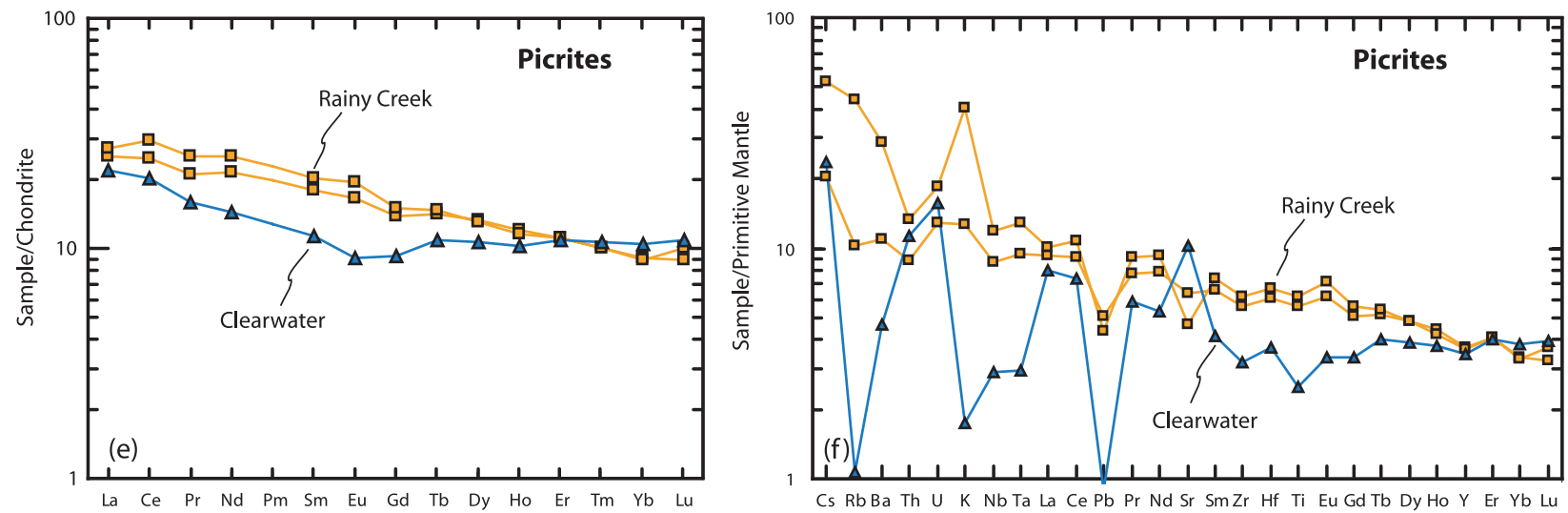

Figure 9. Whole-rock REE and other incompatible-element concentrations for the Nikolai Formation in Alaska. (a, c, and e) Chondrite-normalized REE patterns for high-titanium basalts, low-titanium basalts, and picrites, respectively, from field areas in southern Alaska. (b, d, and f) Primitive mantle-normalized trace element patterns for high-titanium basalts, low-titanium basalts, and picrites, respectively. All normalization values are from McDonough and Sun [1995]. Depleted MORB average from Salters and Stracke [2004]. Note the clear distinction between LREE-enriched hightitanium basalt and mostly LREE-depleted low-titanium basalts. Trace element patterns for the basal flow-conglomerate and one Clearwater sample are not shown in Figure 9d for clarity.

[19] The low-titanium basalts are characterized by a range of flat and slightly light rare earth element (LREE) -depleted chondrite-normalized REE patterns (mean $\mathrm{La} / \mathrm{Sm}_{\mathrm{CN}}=0.8 \pm 0.5$, except one LREE-enriched sample) with flat, parallel heavy
REE (HREE) segments (mean $\mathrm{Dy} / \mathrm{Yb}_{\mathrm{CN}}=1.0 \pm$ 0.2 ; Figure 9). The high-titanium basalts form a tight range of parallel LREE-enriched patterns (mean $\mathrm{La} / \mathrm{Yb}_{\mathrm{CN}}=2.3 \pm 0.9$ ) with higher REE abundances (mean $\mathrm{Yb}_{\mathrm{CN}}=16.1 \pm 6.4$ ) than the 

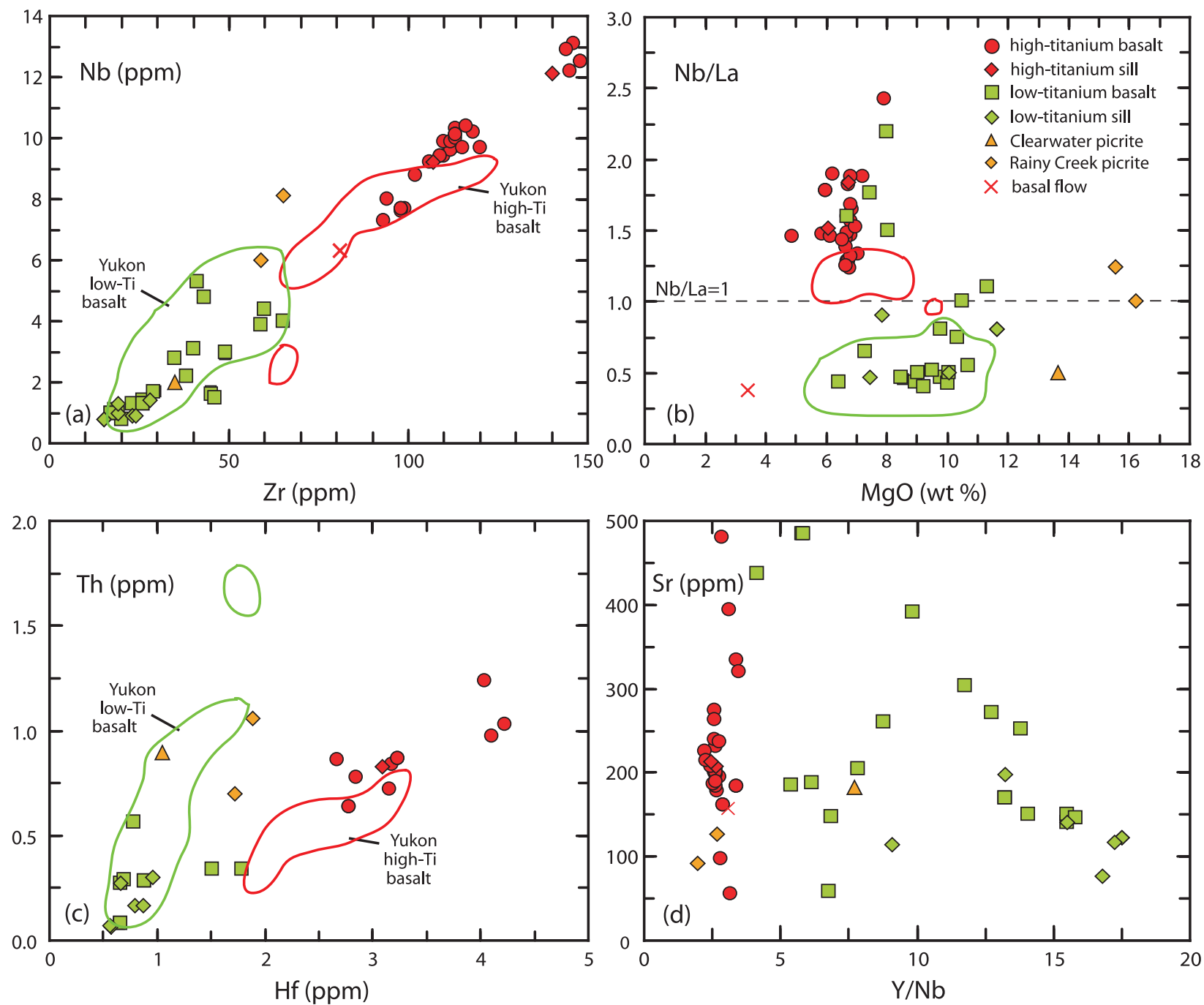

Figure 10. Whole-rock trace element concentration (in ppm) variations and ratios for the Nikolai Formation in Alaska (except Figure 10b is versus $\mathrm{MgO}$ in wt. \%), with fields for the Nikolai Formation in Yukon. (a) Nb versus Zr. (b) $\mathrm{Nb} / \mathrm{La}$ versus $\mathrm{MgO}$. (c) Th versus Hf. (d) Sr versus $\mathrm{Y} / \mathrm{Nb}$ (Yukon fields not shown). Note the clear distinction between the high- and low-titanium basalts in each of the plots. Fields for Nikolai basalts in Yukon are green for lowTi basalts and red for high-Ti basalts.

low-titanium basalts (mean $\mathrm{Yb}_{\mathrm{CN}}=11.0 \pm 2.2$; Figure 9). Several low-titanium basalts from the Amphitheater Mountains have positive Eu anomalies (Figure 9). Two high-titanium basalts from the Wrangell Mountains have patterns with flatter HREE segments. The basal flow-conglomerate from the Wrangell Mountains has a distinct LREE-enriched pattern $\left(\mathrm{La} / \mathrm{Sm}_{\mathrm{CN}}=2.7\right)$ with a flat HREE segment $\left(\mathrm{Dy} / \mathrm{Yb}_{\mathrm{CN}}=1.2\right)$. The Rainy Creek picrites are LREE-enriched $\left(\mathrm{La} / \mathrm{Yb}_{\mathrm{CN}}=\right.$ 2.8-3.1) and the REE pattern of the Clearwater picrite is LREE-enriched $\left(\mathrm{La} / \mathrm{Sm}_{\mathrm{CN}}=1.9\right)$ with a flat HREE segment $\left(\mathrm{Dy} / \mathrm{Yb}_{\mathrm{CN}}=1.0\right)$.
[20] The low-titanium basalts have mostly parallel, primitive mantle-normalized trace element patterns with pronounced high field strength element (HFSE) depletions, especially for $\mathrm{Nb}$, Ta, and $\mathrm{Zr}$, relative to LILE and REE (Figure 9), and the HFSE $(\mathrm{Nb}$ and $\mathrm{Zr}$ ) form linear trends in binary diagrams (Figure 10). The LILE segments of trace element patterns for low-titanium basalts are parallel and each of the patterns has a pronounced positive $\mathrm{Sr}$ anomaly, relative to $\mathrm{Nd}$ and $\mathrm{Sm}$. The high-titanium basalts form a tight range of parallel, concavedownward extended trace element patterns with negative $\mathrm{Pb}$ anomalies, relative to $\mathrm{Ce}$ and $\mathrm{Pr}$, and small negative $\mathrm{K}$ anomalies, relative to $\mathrm{U}$ and $\mathrm{Nb}$ 

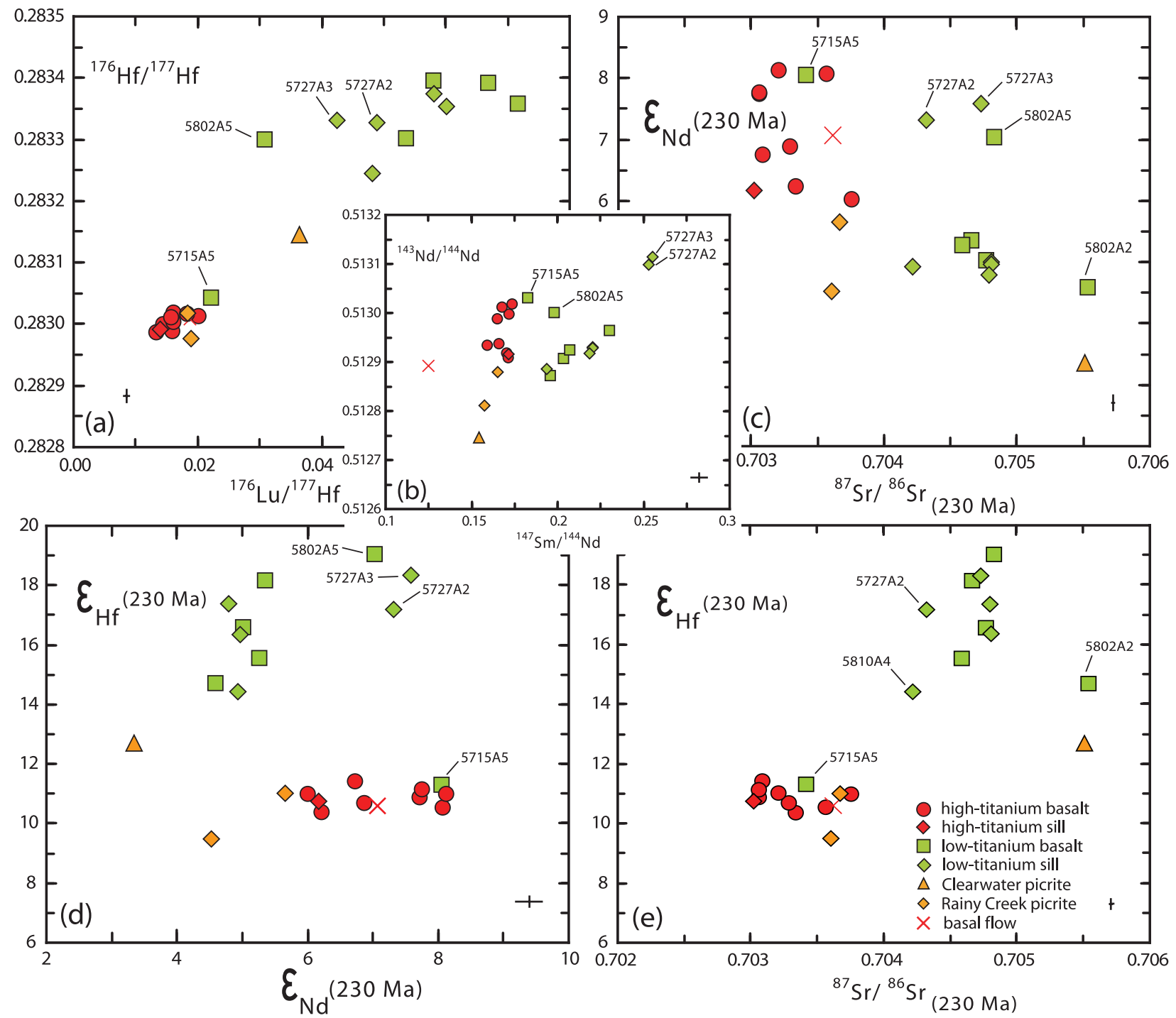

. 


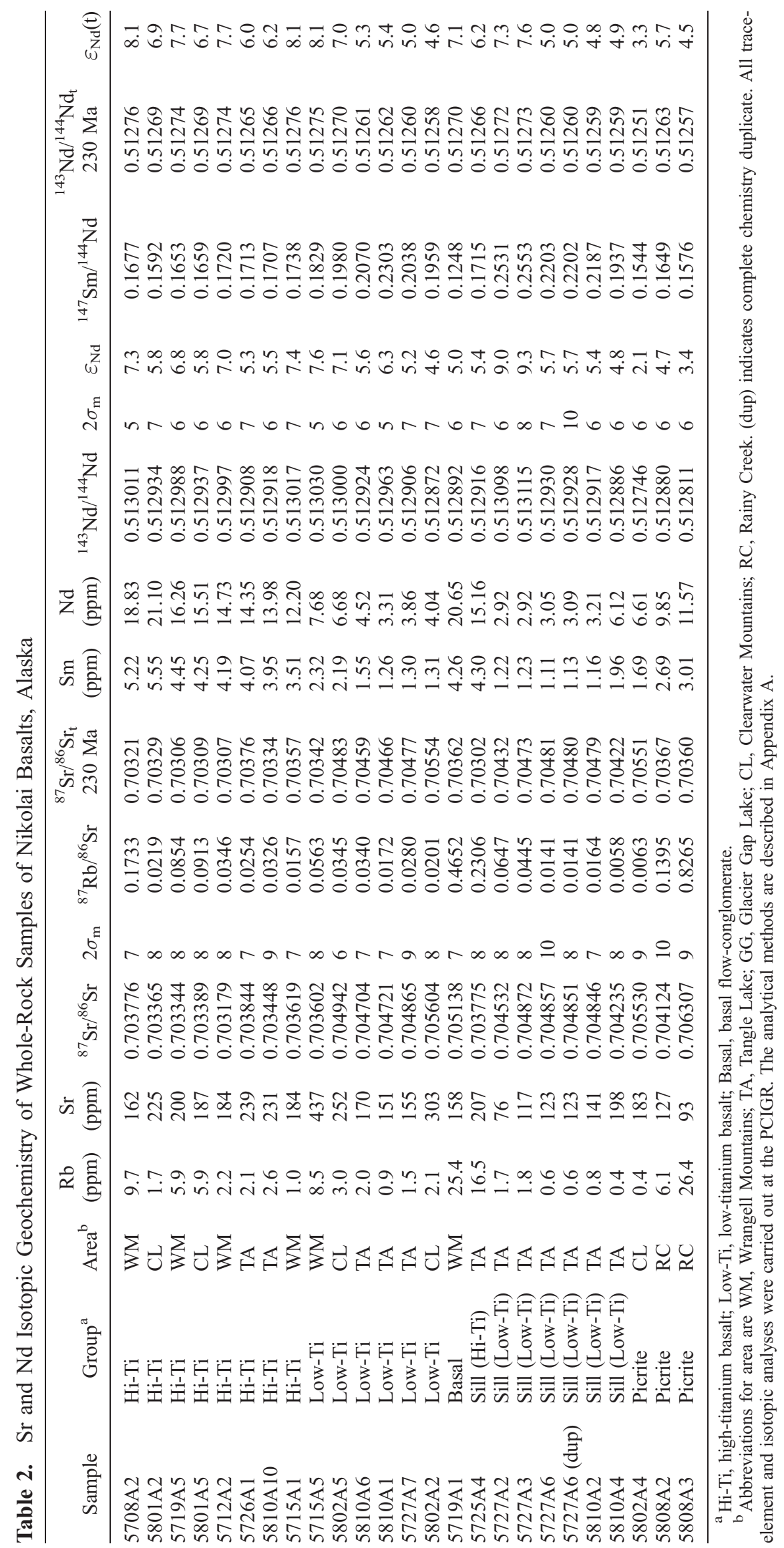


Table 3. Hf Isotopic Compositions of Whole-Rock Samples of Nikolai Basalts, Alaska

\begin{tabular}{|c|c|c|c|c|c|c|c|c|c|c|}
\hline Sample & Group $^{a}$ & Area $^{b}$ & $\begin{array}{c}\mathrm{Lu} \\
(\mathrm{ppm})\end{array}$ & $\begin{array}{c}\mathrm{Hf} \\
(\mathrm{ppm})\end{array}$ & ${ }^{176} \mathrm{Hf} /{ }^{177} \mathrm{Hf}$ & $2 \sigma_{\mathrm{m}}$ & $\varepsilon_{\mathrm{Hf}}$ & ${ }^{176} \mathrm{Lu} /{ }^{177} \mathrm{Hf}$ & $\begin{array}{c}{ }^{176} \mathrm{Hf} /{ }^{177} \mathrm{Hf}_{\mathrm{t}} \\
230 \mathrm{Ma}\end{array}$ & $\varepsilon_{\mathrm{Hf}}(\mathrm{t})$ \\
\hline 5708A2 & Hi-Ti & WM & 0.53 & 4.10 & 0.283016 & 5 & 8.6 & 0.0184 & 0.282935 & 11.0 \\
\hline 5801A2 & $\mathrm{Hi}-\mathrm{Ti}$ & CL & 0.38 & 4.03 & 0.282986 & 6 & 7.6 & 0.0134 & 0.282926 & 10.7 \\
\hline 5719A5 & Hi-Ti & WM & 0.36 & 3.23 & 0.283009 & 6 & 8.4 & 0.0159 & 0.282939 & 11.1 \\
\hline 5801A5 & Hi-Ti & CL & 0.36 & 3.17 & 0.283018 & 7 & 8.7 & 0.0161 & 0.282947 & 11.4 \\
\hline 5712A2 & $\mathrm{Hi}-\mathrm{Ti}$ & WM & 0.36 & 3.15 & 0.283003 & 6 & 8.2 & 0.0162 & 0.282931 & 10.8 \\
\hline 5726A1 & $\mathrm{Hi}-\mathrm{Ti}$ & TA & 0.27 & 2.66 & 0.282999 & 6 & 8.0 & 0.0146 & 0.282934 & 11.0 \\
\hline 5810A 10 & Hi-Ti & TA & 0.32 & 2.84 & 0.282988 & 6 & 7.6 & 0.0160 & 0.282917 & 10.3 \\
\hline $5715 \mathrm{~A} 1$ & $\mathrm{Hi}-\mathrm{Ti}$ & WM & 0.40 & 2.78 & 0.283012 & 5 & 8.5 & 0.0202 & 0.282922 & 10.5 \\
\hline 5715A5 & Low-Ti & WM & 0.28 & 1.79 & 0.283042 & 6 & 9.6 & 0.0223 & 0.282943 & 11.3 \\
\hline 5802A5 & Low-Ti & $\mathrm{CL}$ & 0.33 & 1.51 & 0.283299 & 14 & 18.6 & 0.0309 & 0.283162 & 19.0 \\
\hline 5810A6 & Low-Ti & TA & 0.33 & 0.88 & 0.283302 & 6 & 18.7 & 0.0537 & 0.283063 & 15.5 \\
\hline 5810A1 & Low-Ti & $\mathrm{TA}$ & 0.27 & 0.66 & 0.283396 & 5 & 22.1 & 0.0581 & 0.283137 & 18.1 \\
\hline $5727 \mathrm{~A} 7$ & Low-Ti & $\mathrm{TA}$ & 0.33 & 0.70 & 0.283390 & 7 & 21.9 & 0.0670 & 0.283092 & 16.6 \\
\hline 5802A2 & Low-Ti & CL & 0.39 & 0.78 & 0.283358 & 7 & 20.7 & 0.0717 & 0.283039 & 14.7 \\
\hline 5719A1 & Basal & WM & 0.31 & 2.30 & 0.283008 & 6 & 8.3 & 0.0188 & 0.282924 & 10.6 \\
\hline $5725 \mathrm{~A} 4$ & Sill (Hi-Ti) & TA & 0.30 & 3.08 & 0.282991 & 5 & 7.7 & 0.0141 & 0.282928 & 10.7 \\
\hline 5727A2 & Sill (Low-Ti) & TA & 0.27 & 0.80 & 0.283328 & 7 & 19.7 & 0.0489 & 0.283110 & 17.2 \\
\hline $5727 \mathrm{~A} 3$ & Sill (Low-Ti) & TA & 0.26 & 0.87 & 0.283331 & 9 & 19.8 & 0.0425 & 0.283142 & 18.3 \\
\hline 5727A6 & Sill (Low-Ti) & TA & 0.24 & 0.57 & 0.283354 & 8 & 20.6 & 0.0602 & 0.283086 & 16.3 \\
\hline 5810A2 & Sill (Low-Ti) & TA & 0.27 & 0.66 & 0.283374 & 6 & 21.3 & 0.0581 & 0.283115 & 17.4 \\
\hline $5810 \mathrm{~A} 4$ & Sill (Low-Ti) & TA & 0.32 & 0.96 & 0.283245 & 8 & 16.7 & 0.0481 & 0.283031 & 14.4 \\
\hline $5802 \mathrm{~A} 4$ & Picrite & $\mathrm{CL}$ & 0.27 & 1.05 & 0.283145 & 6 & 13.2 & 0.0365 & 0.282983 & 12.7 \\
\hline 5808A2 & Picrite & $\mathrm{RC}$ & 0.22 & 1.71 & 0.283017 & 7 & 8.7 & 0.0184 & 0.282935 & 11.0 \\
\hline 5808A3 & Picrite & $\mathrm{RC}$ & 0.25 & 1.88 & 0.282977 & 6 & 7.2 & 0.0189 & 0.282893 & 9.5 \\
\hline
\end{tabular}

\footnotetext{
${ }^{\mathrm{a}} \mathrm{Hi}$-Ti, high-titanium basalt; Low-Ti, low-titanium basalt; Basal, basal flow-conglomerate.

${ }^{\mathrm{b}}$ Abbreviations for area are WM, Wrangell Mountains; TA, Tangle Lake; GG, Glacier Gap Lake; CL, Clearwater Mountains; RC, Rainy Creek. All trace-element and isotopic analyses were carried out at the PCIGR. The analytical methods are described in Appendix A.
}

isotope ratios to high-titanium basalts with slightly lower initial $\varepsilon_{\mathrm{Nd}}$ (Figure 11).

[22] The high- and low-titanium basalts have indistinguishable age-corrected $\mathrm{Pb}$ isotopic compositions, although the high-titanium basalts show a narrower range (Figure 12). The range of initial $\mathrm{Pb}$ isotopic compositions for low-titanium basalts is ${ }^{206} \mathrm{~Pb} /{ }^{204} \mathrm{~Pb}=18.421-19.418,{ }^{207} \mathrm{~Pb} /{ }^{204} \mathrm{~Pb}=$ $15.568-15.609$, and ${ }^{208} \mathrm{~Pb} /{ }^{204} \mathrm{~Pb}=37.962-$ 38.481 and the high-titanium basalts have ${ }^{206} \mathrm{~Pb} /{ }^{204} \mathrm{~Pb}=18.504-18.888,{ }^{207} \mathrm{~Pb} /{ }^{204} \mathrm{~Pb}=$ $15.556-15.587$, and ${ }^{208} \mathrm{~Pb} /{ }^{204} \mathrm{~Pb}=38.008-38.451$ (Figure 12; Table 4). The basal flow-conglomerate has a slightly lower initial $\mathrm{Pb}$ isotopic composition than the high- and low-titanium basalts. The Clearwater picrite has a lower initial $\mathrm{Pb}$ isotope ratio than the basalts and the Rainy Creek picrites have noticeably higher initial $\mathrm{Pb}$ isotope ratios than the basalts (Figure 12).

\section{Alteration}

[23] The Nikolai basalts generally preserve primary mineralogical, textural, and volcanological features and have retained most of their primary magmatic composition. Secondary minerals have replaced variable, but generally small, proportions of primary minerals in the Nikolai Formation and the basalts contain zeolite to prehnite-pumpellyite facies alteration minerals (prehnite + pumpellyite + epidote + chlorite + quartz \pm laumonite), primarily making up the amygdules [Stout, 1976; Smith, 1981; MacKevett et al., 1997]. Many of the Nikolai basalts in the synform in the Amphitheater Mountains are exceptionally unaltered compared to flows in the Wrangell and Clearwater Mountains. Vesicles and interpillow voids in the Amphitheater Mountains commonly remain unfilled and secondary minerals are less common.

[24] Seventeen of the 21 low-titanium basalts have LOI greater than $2.5 \mathrm{wt} \%$ and greater than $8 \mathrm{wt} \%$ $\mathrm{MgO}$, whereas only four high-titanium basalts have greater than $2.5 \mathrm{wt} \%$ LOI and all have less than 8 wt $\% \mathrm{MgO}$ (Figure 13). Three of the four hightitanium basalts that lie within the alkalic field are plagioclase-rich, highly amygdaloidal, and were collected near a mineralized area at the top of the Nikolai Formation. Tight linear arrays are apparent on plots of HFSE and REE (not shown) indicating negligible affect of element mobility. Only a limited group of samples (5808A3, 5802A4, 5802A2, 

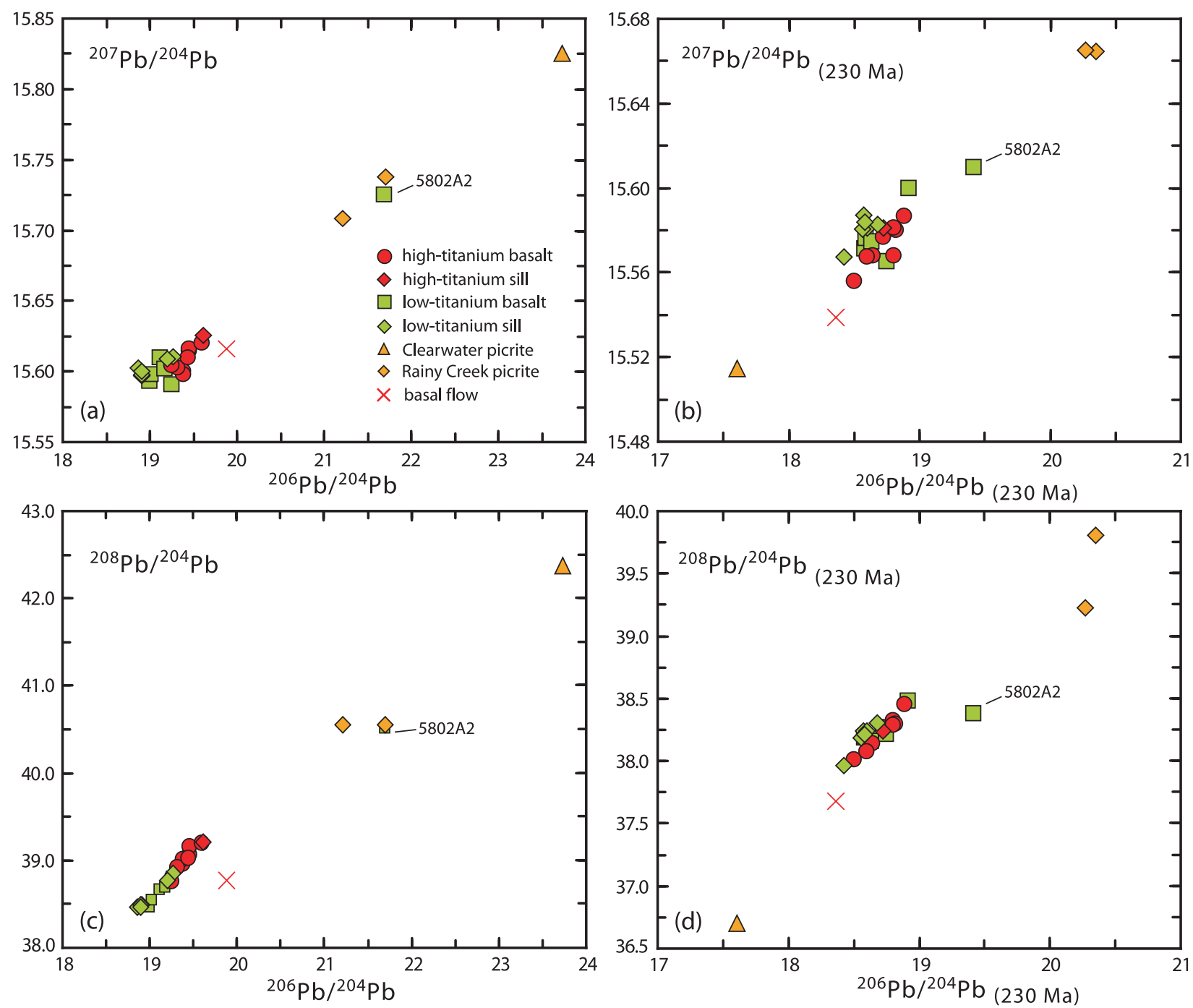

Figure 12. $\mathrm{Pb}$ isotopic compositions of leached whole-rock samples by MC-ICP-MS for the Nikolai Formation in Alaska. Error bars are smaller than symbol size. (a) Measured ${ }^{207} \mathrm{~Pb} /{ }^{204} \mathrm{~Pb}$ versus ${ }^{206} \mathrm{~Pb} /{ }^{204} \mathrm{~Pb}$. (b) Initial ${ }^{207} \mathrm{~Pb} /{ }^{204} \mathrm{~Pb}$ versus ${ }^{206} \mathrm{~Pb} /{ }^{204} \mathrm{~Pb}$; age correction to $230 \mathrm{Ma}$. (c) Measured ${ }^{208} \mathrm{~Pb} /{ }^{204} \mathrm{~Pb}$ versus ${ }^{206} \mathrm{~Pb} /{ }^{204} \mathrm{~Pb}$. (d) Initial ${ }^{208} \mathrm{~Pb} /{ }^{204} \mathrm{~Pb}$ versus ${ }^{206} \mathrm{~Pb} /{ }^{204} \mathrm{~Pb}$.

5725A4, 5726A1) have LILE concentrations outside the narrow range of most high- and low-titanium basalts (Figure 9) and there is no correlation between LOI and LILE. All of the low-titanium basalts have positive $\mathrm{Sr}$ anomalies that are complemented with small positive $\mathrm{Eu}$ anomalies in most samples, and none of the high-titanium basalts have $\mathrm{Sr}$ anomalies (Figure 9), which indicates $\mathrm{Sr}$ concentrations probably represent primary values. $\mathrm{U}$ and $\mathrm{Th}$ show a linear relationship, whereas $\mathrm{Pb}$ and Th do not show a clear relationship (not shown), indicating some secondary mobility of $\mathrm{Pb}$, especially in the low-titanium basalts.

[25] Initial Hf isotopic ratios, and to a lesser extent $\mathrm{Sr}$ and $\mathrm{Pb}$ isotopic compositions, are close to magmatic compositions. Several of the more altered samples were not selected for isotopic analyses and leaching effectively removed most of the secondary alteration products [e.g., Weis et al., 2006; Nobre Silva et al., 2008]. Whole-rock Sm/Nd ratios and age-corrected $\mathrm{Nd}$ isotopes, however, may be affected by the leaching procedure in submarine rocks older than $\sim 50 \mathrm{Ma}$ [Thompson et al., 2008] and this may have caused a small degree of variation between $\mathrm{Nd}$ isotope ratios, especially for the lowtitanium basalts (Figure 11). The Clearwater picrite (5802A4) was significantly affected by $\mathrm{Pb}$ loss and has less radiogenic age-corrected $\mathrm{Pb}$ isotopic ratios than the basalts (Figures 9 and 12). The correlation of LOI and ${ }^{87} \mathrm{Sr} /{ }^{86} \mathrm{Sr},{ }^{206} \mathrm{~Pb} /{ }^{204} \mathrm{~Pb}$, and ${ }^{238} \mathrm{U} /{ }^{204} \mathrm{~Pb}$ in the low- and high-titanium basalts 


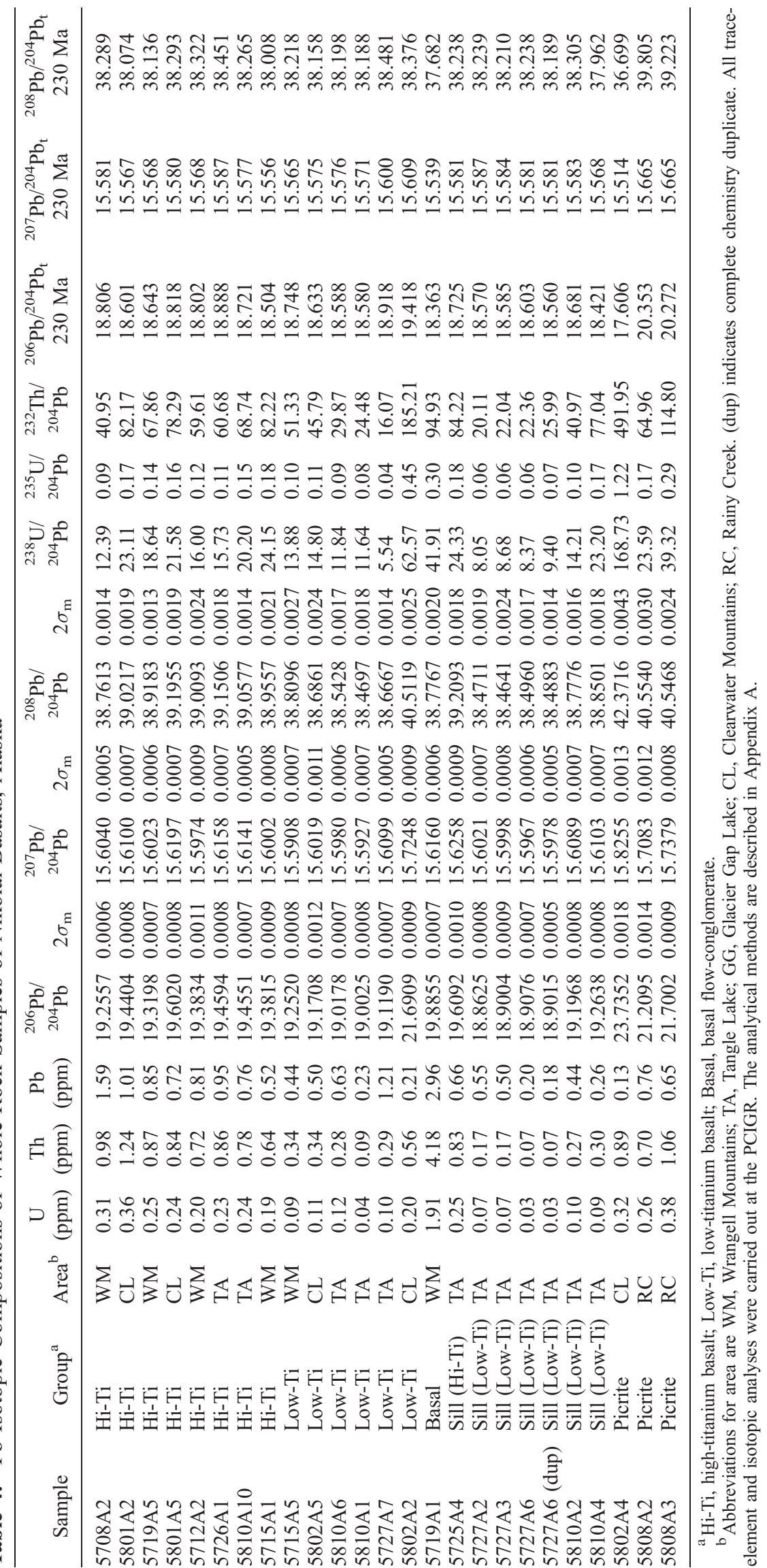



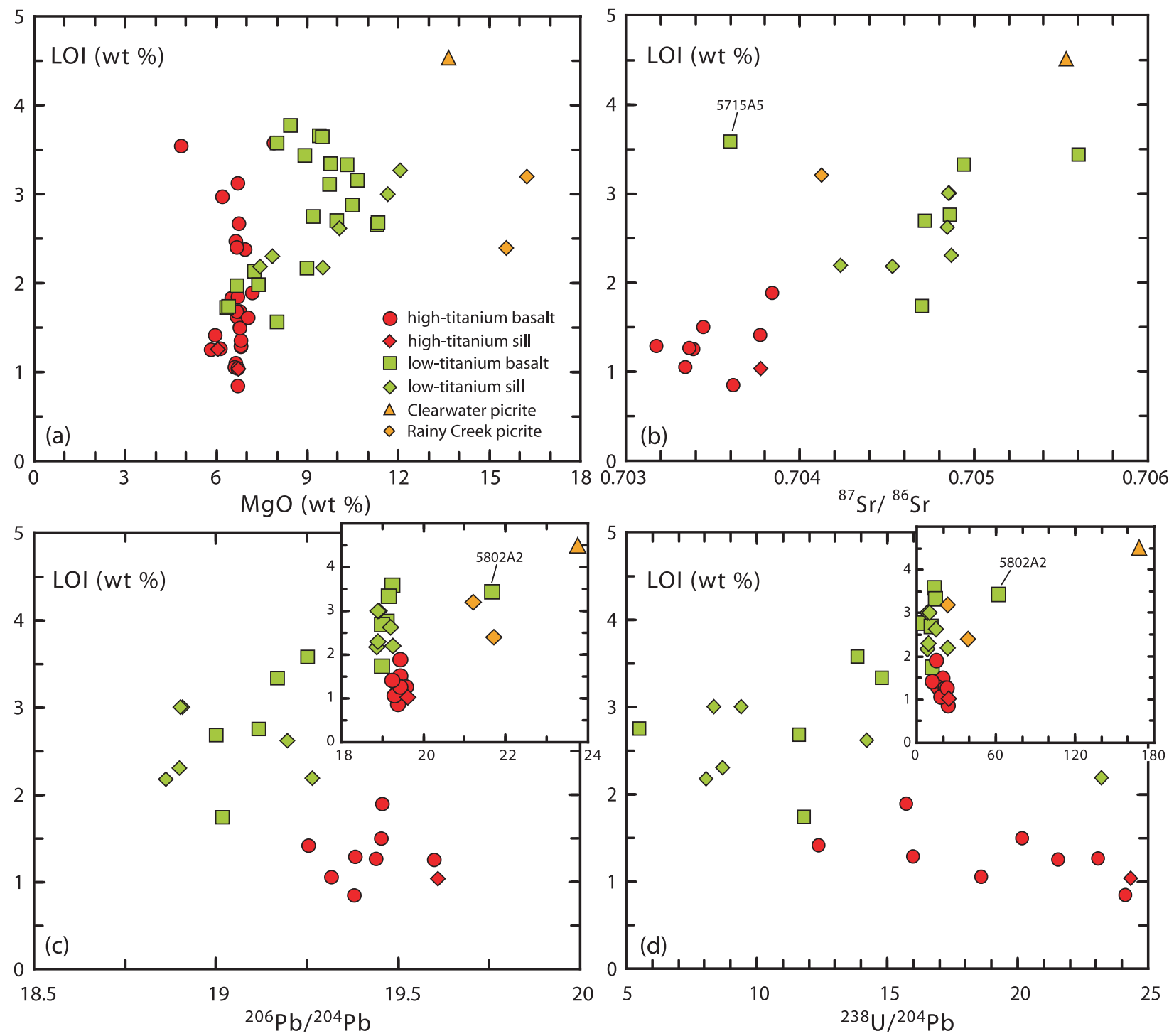

Figure 13. Loss-on-ignition versus $\mathrm{MgO}$ and isotopic ratios for the Nikolai Formation in Alaska. (a) LOI versus MgO. (b) LOI versus measured ${ }^{87} \mathrm{Sr} /{ }^{86} \mathrm{Sr}$. (c) LOI versus measured ${ }^{206} \mathrm{~Pb} /{ }^{204} \mathrm{~Pb}$. (d) LOI versus measured ${ }^{238} \mathrm{U} /{ }^{206} \mathrm{~Pb}$. The two insets show the expanded $x$ axis for ${ }^{206} \mathrm{~Pb} /{ }^{204} \mathrm{~Pb}$ and ${ }^{238} \mathrm{U} /{ }^{206} \mathrm{~Pb}$. Note the generally higher LOI and $\mathrm{MgO}$ for the low-titanium basalts. The differences in measured ${ }^{87} \mathrm{Sr} /{ }^{86} \mathrm{Sr}$ and ${ }^{206} \mathrm{~Pb} /{ }^{204} \mathrm{~Pb}$ within the suites of high- and lowtitanium basalts are mostly not apparent after age correction.

is a primary feature that is not apparent with age correction (Figure 13). The rather small range of initial $\mathrm{Pb}$ and distinct initial $\mathrm{Hf}$ and $\mathrm{Sr}$ isotopic compositions for high- and low-titanium basalts reflects the isotopic compositions of the sources of Wrangellia flood basalts in Alaska.

\section{Flood Basalt Chemostratigraphy}

[26] Samples of the Nikolai Formation were collected traversing both upsection and downsection through the volcanic stratigraphy. An estimate of the relative stratigraphic position of each sample was assigned, which was then used to determine the relationship between stratigraphic position and chemical composition. Figure 14 shows sample numbers, lithologies, relative stratigraphic height, and $\mathrm{TiO}_{2}$ and $\mathrm{MgO}$ contents for Nikolai basalts from the three main areas of Alaska where fieldwork was undertaken (Figure 1). Each stratigraphic column is a combination of multiple traverses (separated by dashed lines in Figure 14). We are 
Geochemistry

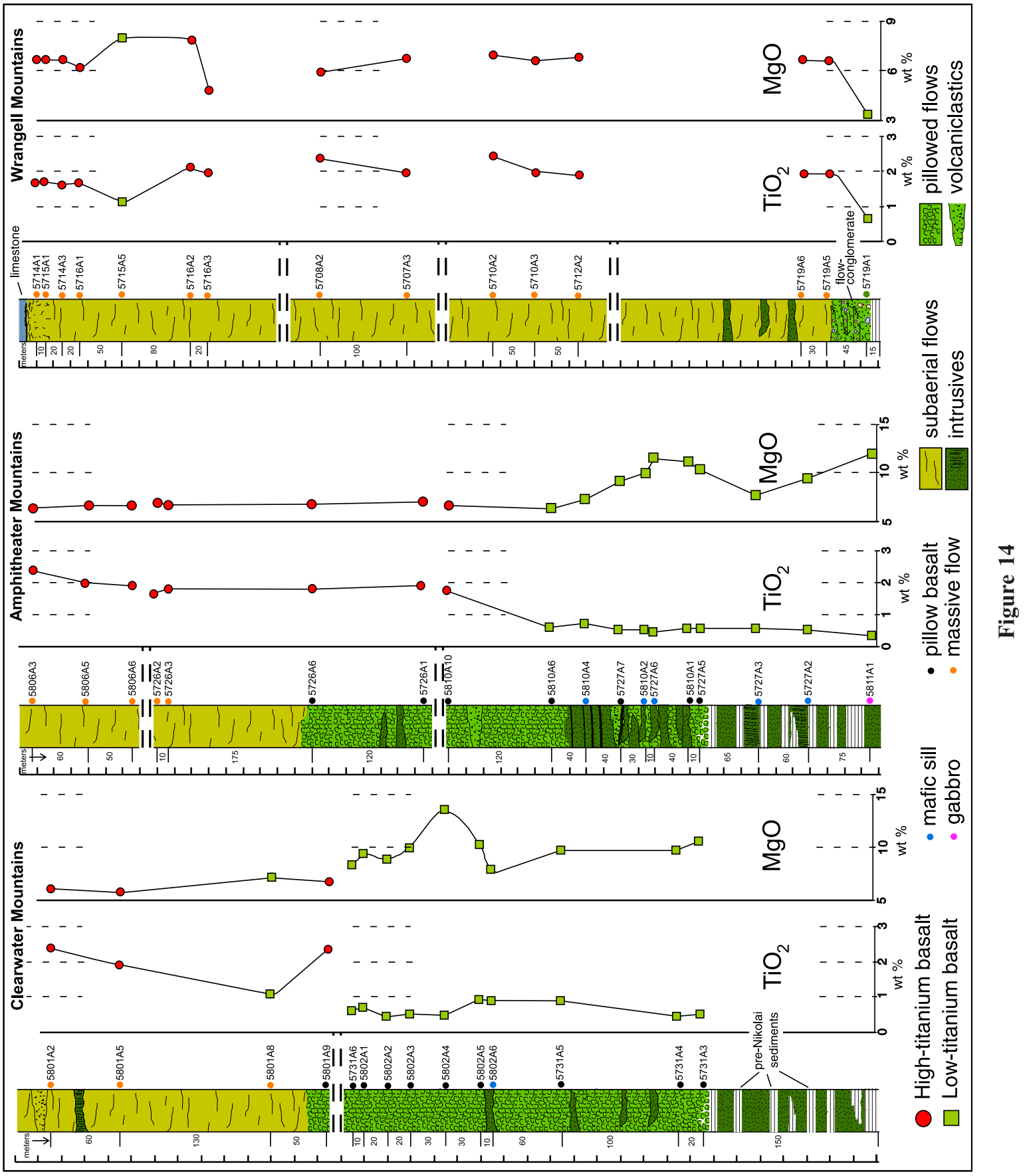


confident in the relative position of each section of stratigraphy based on the continuous exposure and minimal disruption by faults in these areas. As the trace element and isotopic variations of the basalts generally correspond with variation in $\mathrm{TiO}_{2}$ (Figures 8-11), only $\mathrm{TiO}_{2}$ and $\mathrm{MgO}$ are shown in Figure 14.

[27] In the Clearwater and Amphitheater Mountains, there is a clear relationship between stratigraphic position and chemical composition of the flood basalts (Figure 14). The low-titanium basalts form the lowermost several hundred meters of flows ( $\sim 10-15 \%$ of stratigraphy) and the hightitanium basalts form the majority of the flows ( $~ 85-90 \%$ of stratigraphy) above the lowest several hundred meters. More of the low-titanium basalts and sills were sampled, partly because the lower sections of volcanic stratigraphy were more easily accessible and partly because there are more interesting relationships with pre-Nikolai sediments and mafic sills and submarine units preserved lower in the stratigraphy. The transition from low- to high-titanium basalts does not appear to coincide with the transition from submarine to subaerial flows, but almost all of the low-titanium basalts that were sampled are submarine flows.

[28] In the Wrangell Mountains, there do not appear to be any low-titanium basalts, except for two anomalous samples (Figure 14). A single sample of the basal flow-conglomerate has a low titanium content $(0.67 \mathrm{wt} \%)$, similar initial $\varepsilon_{\mathrm{Hf}}$ to the high-titanium basalts, and anomalous $\mathrm{La} / \mathrm{Yb}_{\mathrm{CN}}$ (6.4), $\mathrm{Ba}$ (1277 ppm), and Th (4.18 ppm; Figures 8 and 9; Tables 1 and 3). Field observations and several other geochemical characteristics indicate the chemistry of this basal flow conglomerate is the result of considerable assimilation ( $\sim 30 \mathrm{vol} \%)$ of material derived from underlying Paleozoic sequences. The next sample upsection, $\sim 20 \mathrm{~m}$ above the uppermost exposure of basal flowconglomerate in the Wrangell Mountains, does not have visible assimilated material and is hightitanium basalt with normal chemistry. A single sample with a low titanium content (1.14 wt \% $\mathrm{TiO}_{2} ; 5715 \mathrm{~A} 5$ ) was collected from near the top of the stratigraphy in the Wrangell Mountains, but this sample has similar isotopic composition to the high-titanium basalts, atypical petrographic texture, and is at the upper range of $\mathrm{TiO}_{2}$ of low-titanium basalts.

\section{Discussion}

\subsection{Source of Nikolai Basalts}

[29] The Nikolai Formation in Alaska has two main lava types with distinct isotopic compositions. The high-titanium basalts in Alaska have depleted $\mathrm{Hf}$ and Nd isotopic compositions, although they are not as depleted as most Pacific and Indian midocean ridge basalts (MORB), and overlap and are displaced just below the ocean island basalt (OIB) mantle array (Figure 15). The high-titanium basalts have similar initial $\mathrm{Sr}$ and $\mathrm{Nd}$ isotopic compositions to Ontong Java Plateau, Hawaii, and Caribbean Plateau basalts and similar initial $\varepsilon_{\mathrm{Hf}}$ to Ontong Java, with slightly lower initial $\varepsilon_{\mathrm{Hf}}$ than most Hawaii and Caribbean basalts (Figure 15). In contrast, the low-titanium basalts are displaced well above the OIB mantle array in a $\varepsilon_{\mathrm{Hf}}(\mathrm{t})-$ $\varepsilon_{\mathrm{Nd}}(\mathrm{t})$ correlation diagram and have higher initial $\varepsilon_{\mathrm{Hf}}$ than age-corrected Pacific MORB at $230 \mathrm{Ma}$, with lower initial $\varepsilon_{\mathrm{Nd}}$ than age-corrected Pacific MORB by 3 epsilon units. The Hf isotopic compositions of the low-titanium basalts are 2 to 6 epsilon units higher than most samples from Ontong Java, which have comparable to slightly lower initial $\varepsilon_{\mathrm{Nd}}$. Sr isotopic compositions for lowtitanium basalts extend to significantly higher initial ${ }^{87} \mathrm{Sr} /{ }^{86} \mathrm{Sr}$ than Ontong Java and Hawaii. Three low-titanium basalts with particularly high initial $\varepsilon_{N d}$ lie within a field for Indian MORB in $\varepsilon_{H f}(t)-$ $\varepsilon_{\mathrm{Nd}}(\mathrm{t})$ space. Two Rainy Creek picrite samples lie close to the $\varepsilon_{\mathrm{Hf}}(\mathrm{t})-\varepsilon_{\mathrm{Nd}}(\mathrm{t})$ OIB mantle array with lower initial $\varepsilon_{\mathrm{Nd}}$ than the high-titanium basalts (Figure 15). The high- and low-titanium basalts have uniform initial $\mathrm{Pb}$ isotopic compositions that overlap the field for Caribbean basalts and have more radiogenic initial ${ }^{207} \mathrm{~Pb} /{ }^{204} \mathrm{~Pb}$ than Ontong Java, Hawaii, and a field for the East Pacific Rise (EPR; Figure 15). $\mathrm{Pb}$ isotopic compositions for the Wrangellia basalts form a linear trend in ${ }^{208} \mathrm{~Pb}-{ }^{206} \mathrm{~Pb}$ space that intersects the field of Pacific MORB compositions and is slightly offset toward lower ${ }^{208} \mathrm{~Pb} /{ }^{204} \mathrm{~Pb}$ from Ontong Java and Hawaii. The Nikolai basalts have more radiogenic $\mathrm{Pb}$ isotopic compositions than MORB, Ontong

Figure 14. Chemostratigraphy of the Nikolai Formation in three areas of Alaska (Clearwater, Amphitheater, and Wrangell Mountains). Each column shows flow type, sample numbers, relative stratigraphic height, and $\mathrm{TiO}_{2}$ and $\mathrm{MgO}$ contents (in wt \%). Dashed lines in each column separate individual traverses. Legend indicates flow type. 

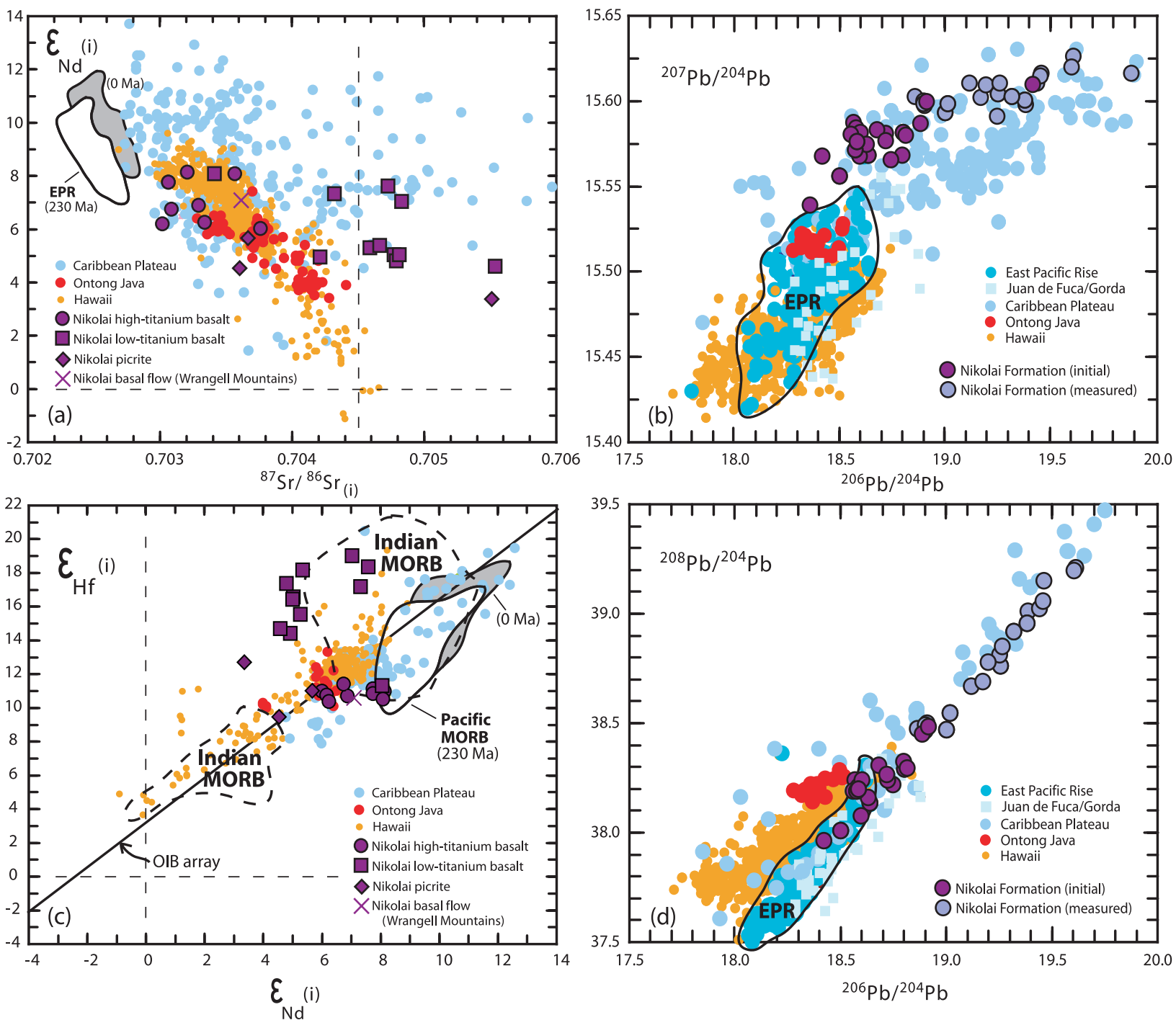

Figure 15. Comparison of age-corrected (230 Ma) Sr-Nd-Hf-Pb isotopic compositions for Nikolai basalts in Alaska to age-corrected OIB and MORB (except for Pb plots). (a) Initial $\varepsilon_{\mathrm{Nd}}$ versus ${ }^{87} \mathrm{Sr} /{ }^{86} \mathrm{Sr}$. (b) Measured and initial ${ }^{207} \mathrm{~Pb} /{ }^{204} \mathrm{~Pb}$ versus ${ }^{206} \mathrm{~Pb} /{ }^{204} \mathrm{~Pb}$. (c) Initial $\varepsilon_{\mathrm{Hf}}$ versus $\varepsilon_{\mathrm{Nd}}$. (d) Measured and initial ${ }^{208} \mathrm{~Pb} /{ }^{204} \mathrm{~Pb}$ versus ${ }^{206} \mathrm{~Pb} /{ }^{204} \mathrm{~Pb}$. References for data sources are listed in Auxiliary Material (Text S2). Most of the compiled data was extracted from the GEOROC database (http://georoc.mpch-mainz.gwdg.de/georoc/). OIB array line from Vervoort et al. [1999]. EPR is East Pacific Rise. Dashed lines indicate Bulk Silicate Earth (BSE). Estimation of fields for age-corrected Pacific MORB and EPR at $230 \mathrm{Ma}$ were made using parent-daughter concentrations (in ppm) from Salters and Stracke [2004] of $\mathrm{Lu}=0.063$, $\mathrm{Hf}=0.202, \mathrm{Sm}=0.27, \mathrm{Nd}=0.71, \mathrm{Rb}=0.086$, and $\mathrm{Sr}=8.36$.

Java, and OIB from Hawaii but are similar to basalts of the Caribbean Plateau.

[30] The initial $\mathrm{Hf}$ and $\mathrm{Nd}$ isotopic compositions of high-titanium basalts indicate a uniform plumetype Pacific mantle source derived from a longterm depleted source, distinct from the source of MORB. In contrast, the low-titanium basalts have initial $\mathrm{Hf}$ isotopic compositions that are clearly distinct from OIB and initial $\mathrm{Nd}$ isotopic compo- sitions that are distinct from the Pacific MORB source at $230 \mathrm{Ma}$. The displacement of the lowtitanium basalts well above the OIB array indicates involvement of a depleted component (mantle or crust), distinct from depleted MORB mantle, early in the formation of Nikolai basalts in Alaska. The origin of the isotopic and geochemical signature of the low-titanium basalts is the focus of subsequent discussion sections. 


\subsection{Lithospheric Involvement in Derivation of the Low-Titanium Basalts}

[31] The stratigraphic relationship of the two contrasting lava types in the Nikolai Formation preserves a record of a shift in composition and provides a rare opportunity to evaluate the role of oceanic arc lithosphere in the formation of an oceanic plateau. Thus far, the low-titanium basalts have primarily been recognized in the lowermost part of the stratigraphy in the western part of Wrangellia in Alaska, where there is a substantial section of submarine flows $(\sim 500 \mathrm{~m})$. The lowtitanium basalts have the complete subductionzone trace element signature; they have distinct negative-HFSE anomalies (Nb-Ta and $\mathrm{Zr}-\mathrm{Hf}$ ) and are enriched in LILE. The low-titanium basalts also have Hf-Sr-Nd isotopic compositions that are indicative of a component characterized by high $\mathrm{Rb} /$ $\mathrm{Sr}$, low $\mathrm{Sm} / \mathrm{Nd}$, and high $\mathrm{Lu} / \mathrm{Hf}$; they have high initial $\varepsilon_{\mathrm{Hf}}$ and high initial ${ }^{87} \mathrm{Sr} /{ }^{86} \mathrm{Sr}$ compared to the high-titanium basalts. This compositional and stratigraphic evidence suggests involvement of the Paleozoic arc lithosphere in the generation of early erupted low-titanium basalts in the Wrangellia oceanic plateau of Alaska.

\subsubsection{Nature of Underlying Paleozoic Arc Lithosphere}

[32] The Paleozoic arc (320-285 Ma) and marine sedimentary sequences (Early Permian to Middle Triassic) exposed beneath the Nikolai basalts in Alaska are $>2.5 \mathrm{~km}$ thick in areas [e.g., Nokleberg et al., 1985]. Recent geophysical studies in southern Alaska by Saltus et al. [2007] indicate Wrangellia crust is at least $50 \mathrm{~km}$ thick between the Denali and Border Ranges Faults (Figure 1). The arc crust that the Wrangellia oceanic plateau was built upon may have been $20-30 \mathrm{~km}$ thick and presumably included a substantial subarc lithospheric mantle that was metasomatized during arc activity.

[33] In the Alaska Range, the Nikolai basalts are underlain, in decreasing order of depth, by the Paleozoic Tetelna Volcanics, the Slana Spur, and Eagle Creek Formations. Tetelna Volcanics $(<1000 \mathrm{~m})$ are andesitic and dacitic flows, tuffs interbedded with volcaniclastic rocks, and debris flow deposits; the Slana Spur Formation $(\sim 1400 \mathrm{~m})$ is marine volcaniclastics, with lesser limestone and sandstone; and the Eagle Creek Formation $(\sim 900 \mathrm{~m})$ is Permian argillite and limestone [Nokleberg et al., 1985]. Numerous comagmatic intermediate to felsic plutonic rocks intrude Tetelna Volcanics and the Slan Spur Formation [Nokleberg et al., 1994]. In the Wrangell Mountains, the Paleozoic sequences include the Station Creek Formation $(\sim 1200 \mathrm{~m}$ of mostly basaltic and andesitic flows and $800 \mathrm{~m}$ of volcaniclastic sequences) and the sedimentary Hasen Creek Formation ( $~ 500 \mathrm{~m}$ of chert, black shale, sandstone, bioclastic limestone, and conglomerate) [Smith and MacKevett, 1970; Figure 2]. The late Paleozoic arc sequences beneath the Nikolai basalts in Alaska predate eruption of the Nikolai basalts by $\sim 55-90 \mathrm{Ma}$. They represent an extinct island arc assemblage that existed in the eastern Panthalassic Ocean in the late Paleozoic to Middle Triassic and formed the substrate upon which the Nikolai basalts were emplaced.

\subsubsection{Implications of Trace Element and Isotopic Constraints}

[34] The trace element and isotopic compositions of the early erupted low-titanium basalts are not typical of OIB and indicate involvement of a HFSE-depleted component that was different than the plume-type source of the high-titanium basalts. The arc lithosphere is a key suspect for derivation of the low-titanium basalts because (1) the geochemical and isotopic signature of the low-titanium basalts has very similar characteristics to rocks formed in subduction settings [e.g., Kelemen et al., 2003]; (2) arc crust is exposed beneath the Nikolai basalts in Alaska; and (3) the low-titanium basalts only form $\sim 10-15 \%$ of the lowest part of the volcanic stratigraphy.

[35] Figure 16 highlights differences in trace elements and isotopic compositions between the highand low-titanium basalts. The high-titanium basalts form a concentrated cluster of points in each of the plots and show a remarkably small degree of variation, whereas the low-titanium basalts have a noticeably wider range of variation, which mostly does not overlap the range for the high-titanium basalts (Figure 16). The low-titanium basalts have low $\mathrm{Nb} / \mathrm{Th}$ and $\mathrm{Nb} / \mathrm{La}$ relative to primitive mantle, which is characteristic of subduction-related rocks [Pearce, 1982]. Except for three samples from the basal flow in the Amphitheater Mountains, which has pelagic sediment between pillow tubes derived from the directly underlying strata and has similar $\mathrm{Nb} / \mathrm{Th}$ to the high-titanium basalts, the low-titanium basalts have similar $\mathrm{Nb} / \mathrm{Th}$ and $\mathrm{Nb} / \mathrm{La}$ to accreted arc crust from the Early Jurassic Talkeetna arc exposed in southern Alaska $\sim 50 \mathrm{~km}$ south of the Amphitheater Mountains [Greene et al., 2006; Figure 16]. Low $\mathrm{Nb} / \mathrm{Th}$ in arc magmas is 

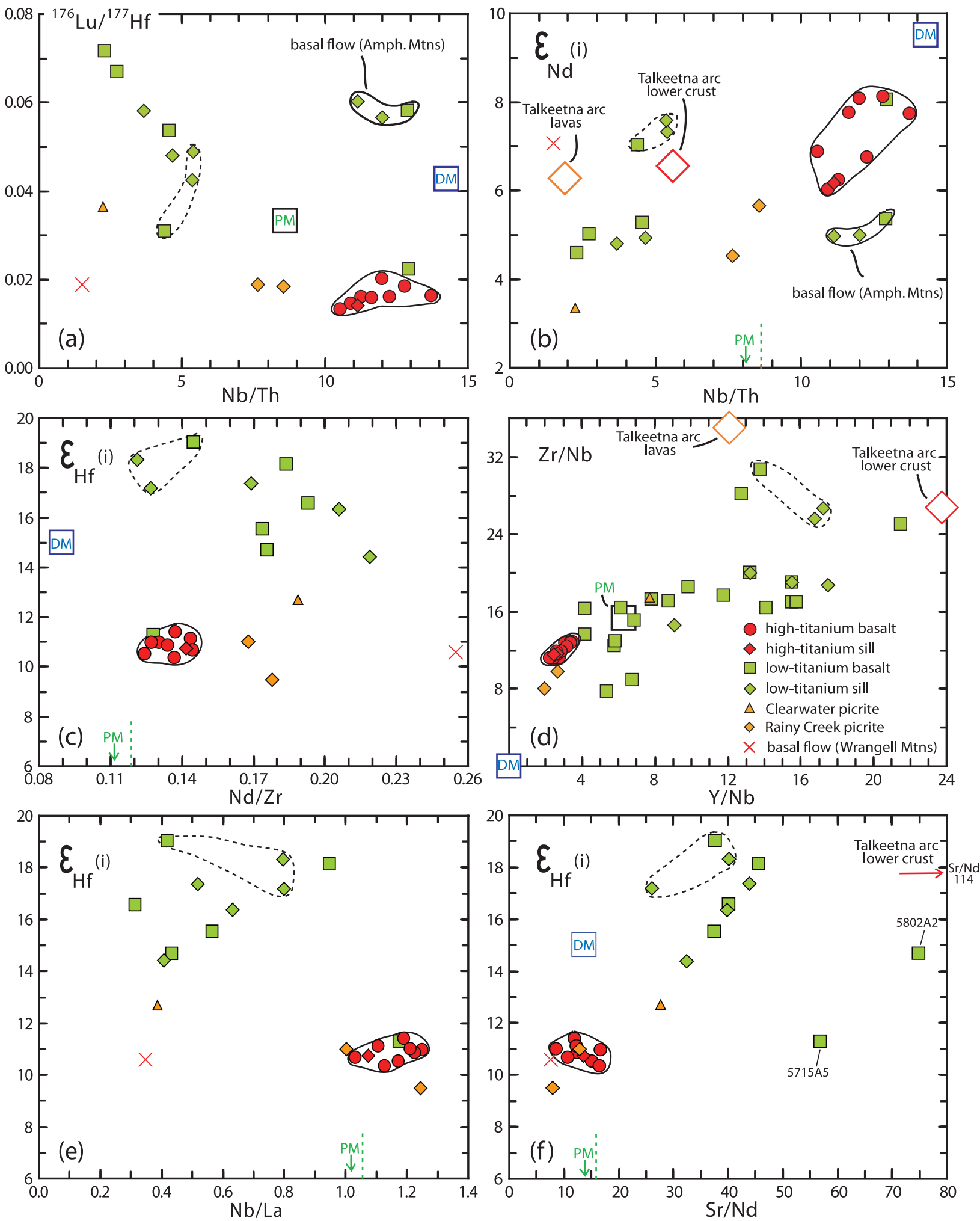

Figure 16. Trace element ratios and isotopic compositions of the Nikolai Formation in Alaska. (a) ${ }^{176} \mathrm{Lu} /{ }^{177} \mathrm{Hf}$ versus $\mathrm{Nb} / \mathrm{Th}$. (b) Initial $\varepsilon_{\mathrm{Nd}}$ versus $\mathrm{Nb} / \mathrm{Th}$. (c) Initial $\varepsilon_{\mathrm{Hf}}$ versus $\mathrm{Nd} / \mathrm{Zr}$. (d) $\mathrm{Zr} / \mathrm{Nb}$ versus $\mathrm{Y} / \mathrm{Nb}$. (e) Initial $\varepsilon_{\mathrm{Hf}}$ versus $\mathrm{Nb} / \mathrm{La}$. (f) Initial $\varepsilon_{\mathrm{Hf}}$ versus Sr/Nd. Primitive mantle (PM) from McDonough and Sun [1995], depleted mantle (DM) from Salters and Stracke [2004]. Talkeetna arc lower crust compositions from Greene et al. [2006] and Talkeetna arc lavas from Clift et al. [2005]. Dashed circles outline samples 5727A2, 5727A3, and 5802A5. 
commonly attributed to inheritance from subducted sediments [e.g., Kelemen et al., 2003]. Low Nb/La may be related to a process whereby migration of REE into magma takes place, but mobilization of $\mathrm{Nb}$ is inhibited, such as by reaction between magmas and metasomatized peridotite [e.g., Kelemen et al., 1990; Kelemen et al., 1993]. The low-titanium basalts have high $\mathrm{Sr} / \mathrm{Nd}$ and $\mathrm{Nd} / \mathrm{Zr}$ relative to primitive mantle and the high-titanium basalts (Figure 16). Elevated Sr relative to REE may indicate addition of $\mathrm{Sr}$ to arc lithosphere through aqueous fluids, since $\mathrm{Sr}$ is more soluble than REE at high pressure [e.g., Johnson and Plank, 1999] or addition from Sr-enriched cumulates from gabbroic lower crust [e.g., Kelemen et al., 2003]. The trace element patterns of the low-titanium basalts have sizable $\mathrm{Sr}$ peaks, and negative $\mathrm{Nb}-\mathrm{Ta}$ and $\mathrm{Zr}-\mathrm{Hf}$ anomalies, that closely resemble those of gabbroic rocks formed in the lower crust of island arcs (e.g., Early Jurassic Talkeetna arc [Greene et al., 2006]).

[36] Figure 17 utilizes proxies described by Pearce [2008] for identifying lithospheric input (Th-Nb) and assessing depth of melting (Ti-Yb). For the Th$\mathrm{Nb}$ proxy, all the high-titanium basalts lie within a diagonal MORB-OIB array parallel to a melting vector, whereas most of the low-titanium basalts are displaced above the array, oblique to the melting vector. The low-titanium basalts follow a trend for lavas that have a subduction component, or have interacted with continental crust, and they are consistent with a relatively small amount of assimilation $(\mathrm{F}>0.9 ; \mathrm{F}$ is melt fraction) combined with fractional crystallization (AFC) as shown by the modeling curve of Pearce [2008; Figure 17]. A $\mathrm{Nb}$-Th-depleted component is indicated for the low-titanium basalts, which also have similar $\mathrm{Nb}-$ Th to Talkeetna arc lavas and lower crust. For the $\mathrm{Ti}-\mathrm{Yb}$ proxy, high $\mathrm{Ti} / \mathrm{Yb}$ ratios for high-titanium basalts indicate residual garnet from melting at high pressure, within the OIB melting array, whereas low-titanium basalts lie along a complementary mantle melt depletion trend, similar to compositions of Talkeetna arc lavas [Pearce, 2008].

[37] The geochemical and isotopic results for the low-titanium basalts from this study support the hypothesis for involvement of a component derived from subarc lithospheric mantle. Lassiter et al. [1995] suggested a minor role for the arc lithosphere in formation of the Nikolai basalts based on a suite of nine samples from the Wrangell Mountains in Alaska. They inferred that assimilation of low $\varepsilon_{\mathrm{Nd}}$, low $\mathrm{Nb} / \mathrm{Th}$ arc material may have affected the composition of the Wrangellia basalts, but that mixing of MORB mantle with low $\varepsilon_{\mathrm{Nd}}$ arc material did not reproduce the trends in the Wrangellia basalts. Rather, Lassiter et al. [1995] suggested mixing of a plume-type source, with $\varepsilon_{\mathrm{Nd}}=$ +6 to +7 , with arc material with low $\mathrm{Nb} / \mathrm{Th}$ could reproduce variations in the Wrangellia flood basalts. They noted that the absence of low $\mathrm{Nb} /$ $\mathrm{La}$ ratios in flood basalts from their data set suggests a restricted amount of lithospheric involvement. The lower $\mathrm{FeO}$ content for most of the low-titanium basalts also may reflect melting generated from refractory arc lithosphere [Lassiter and DePaolo, 1997].

[38] The low-titanium basalts may have developed an arc-type signature by melting of subductionmodified mantle, interaction of plume-derived melts with melts or material derived from the arc lithospheric, and/or reaction of magmas and metasomatized arc peridotite early in generation of the Nikolai basalts. All CFBs show compositional evidence of involvement of lithospheric mantle or continental crust in parts of their volcanic stratigraphy [e.g., Saunders et al., 1992]. Several CFBs and volcanic rifted margins show a transition in the eruptive sequence from a lithospheric to a plumederived signature (e.g., Siberia [Wooden et al., 1993]; Parana [Peate and Hawkesworth, 1996]; North Atlantic Igneous Province [Kerr, 1994]; Ethiopia [Pik et al., 1999]) and a number of influential studies have examined the role of plumelithosphere interactions in the formation of flood basalt provinces [e.g., Arndt and Christensen, 1992; Menzies, 1992; Saunders et al., 1992; Turner et al., 1996; Lassiter and DePaolo, 1997]. White and McKenzie [1995] presented geochemical evidence for continental lithospheric contribution to flood basalts but indicated that the conduction of heat to the lithosphere from the plume is too slow to produce large volumes of magma in short timespans. Arndt and Christensen [1992] found that $>96 \%$ of melt in CFBs comes from the asthenosphere and only minor amounts of melt $(<5 \%)$ may originate in the lithosphere. Although there are conflicts with anhydrous melting models for the lithosphere, Lassiter and DePaolo [1997] found evidence for lithospheric mantle melting and typically these melts are more abundant during early phases of flood volcanism, as they usually represent a minor volume (10-20\%) of the eruptive sequences (e.g., Siberia). Pik et al. [1999] proposed melting of a shallow-level, depleted source for low-titanium basalts from Ethiopia, with a strong, but variable, lithospheric contribution. 

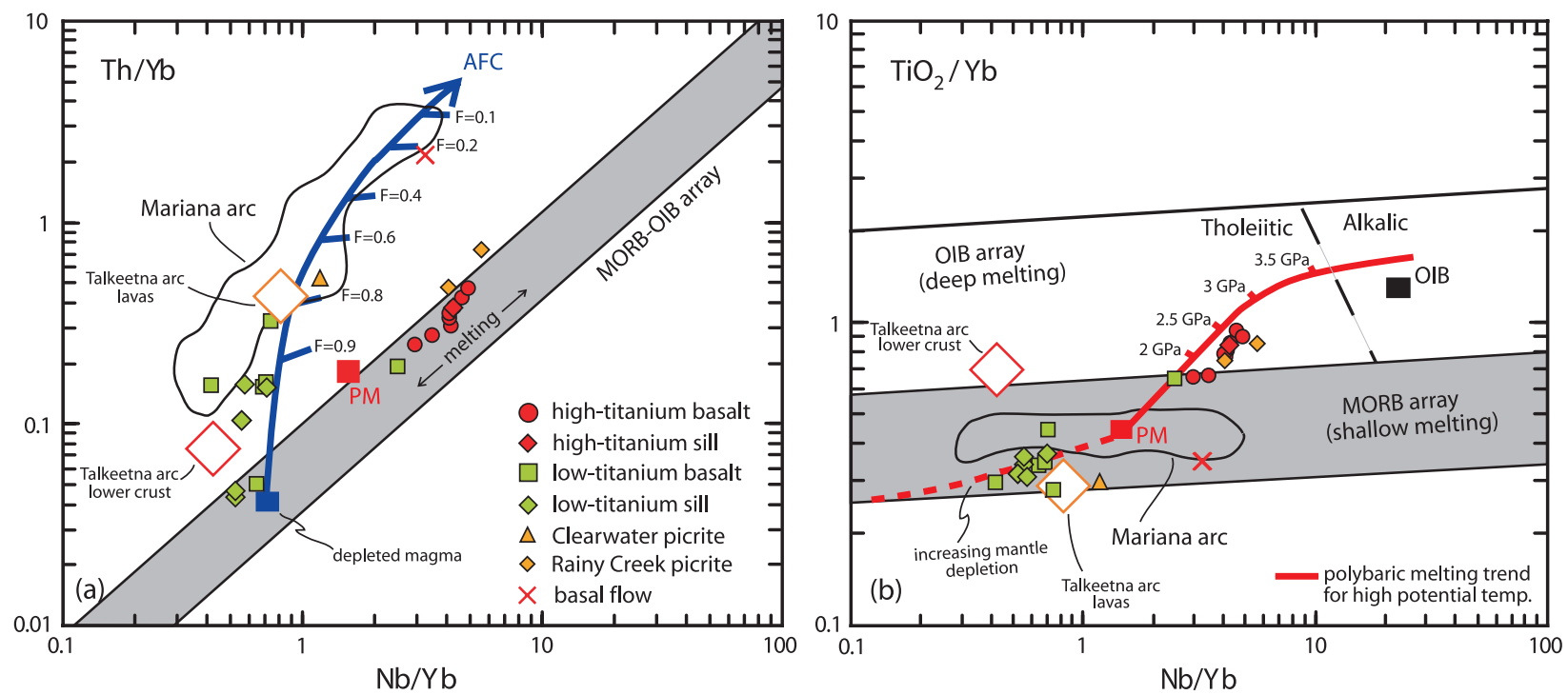

Figure 17. Th- $\mathrm{Nb}$ and $\mathrm{Ti}-\mathrm{Yb}$ proxies of the Nikolai Formation in Alaska with data compilation and modeling results from Pearce [2008]. (a) $\mathrm{Th} / \mathrm{Yb}$ versus $\mathrm{Nb} / \mathrm{Yb}$. MORB-OIB array and assimilation-fractional crystallization (AFC) model from Pearce [2008]. (b) $\mathrm{TiO}_{2} / \mathrm{Yb}$ versus $\mathrm{Nb} / \mathrm{Yb}$. Talkeetna arc lower crust from Greene et al. [2006] and Talkeetna arc lavas from Clift et al. [2005]. Mariana arc data from Pearce et al. [2007] and Woodhead et al. [2001]. The low-titanium basalts indicate a depleted source and interaction with a subduction component combined with fractional crystallization, whereas the high-titanium basalts lie within an OIB array in Figure 17b, parallel to a melting vector that indicates higher pressure melting. See Pearce [2008] for parameters of polybaric melting and assimilation-fractional crystallization (AFC) modeling. Blue line in Figure 17a represents an AFC model following the modeling of DePaolo [1981]. Red line in Figure 17b illustrates a polybaric melting trend (with changing composition of pooled melt extracted from the mantle that undergoes decompression from the solidus to the pressure marked) for high and lower mantle potential temperatures, which corresponds to representative conditions for the generation of present-day MORB and OIB [Pearce, 2008].

[39] For certain conditions (e.g., lithospheric thickness, duration of heating, and temperature), modeling predicts that small volumes of lithosphere-derived basalts may be overlain by larger volumes of asthenospheric basalts [Turner et al., 1996], as is the case for Wrangellia basalts in Alaska. Turner et al. [1996] concluded that the lithospheric mantle can contribute melt if it is less than $100 \mathrm{~km}$ thick and if the solidus is lowered from addition of volatiles at some time in the past. Saunders et al. [1992] suggested that, although conduction alone may not cause melting of the lithosphere, rifting, and decompression, the presence of hydrous phases in subcontinental lithospheric mantle [e.g., Gallagher and Hawkesworth, 1992], melt injection from the plume into the lithosphere, and thermal and mechanical erosion of the lithosphere may all facilitate melting. Numerical modeling of d'Acremont et al. [2003] involving plume head-lithosphere interaction and the formation of oceanic plateaus indicates thermal weakening may be less important than mechanical weakening at timescales of plume head flattening and related strain rates. Farnetani and Richards
[1994] found from numerical modeling, partly applied to Triassic Wrangellia stratigraphy that without extension, melting would likely be entirely sublithospheric; however, they note that they did not examine complexities of arc lithosphere and the presence of hydrous phases that would enhance melting. Although primary hydrous phases are not present in the low-titanium basalts, their origin may have involved melting of subarc lithospheric mantle prior to thinning of the lithosphere or from mechanical or thermal erosion of the base of the lithosphere.

\subsubsection{Origin of Decoupled Hf and Nd Isotopes of Low-Titanium Basalts}

[40] The initial Hf isotopic compositions of the low-titanium basalts indicate involvement of a component that evolved with high $\mathrm{Lu} / \mathrm{Hf}$ over time but not corresponding high $\mathrm{Sm} / \mathrm{Nd}$. Parent isotopes ${ }^{176} \mathrm{Lu}$ and ${ }^{147} \mathrm{Sm}$ are more compatible during melting than their daughter isotopes ${ }^{176} \mathrm{Hf}$ and ${ }^{143} \mathrm{Nd}$, respectively [Salters and White, 1998], and show a close coupling in the crust-mantle system; when plotting $\mathrm{Hf}$ versus $\mathrm{Nd}$ isotopes they 
form the "terrestrial array" [e.g., Vervoort and Blichert-Toft, 1999; van de Flierdt et al., 2004; Figure 18]. A range of processes has been proposed to decouple $\mathrm{Hf}$ and $\mathrm{Nd}$ isotopes. Depleted lithosphere (after MORB extraction) has high Lu/ Hf and moderate $\mathrm{Sm} / \mathrm{Nd}$ and can lead to decoupling [Salters and Zindler, 1995; Salters et al., 2006]. Processes that involve zircon or garnet, which result in larger fractionation of $\mathrm{Lu} / \mathrm{Hf}$ than of $\mathrm{Sm} / \mathrm{Nd}$ [e.g., Patchett et al., 1984; Vervoort et $a l ., 2000]$, can drive $\mathrm{Hf}$ and $\mathrm{Nd}$ isotopic compositions from the terrestrial array. These processes may involve pelagic sediment, ancient melt extraction, or oceanic lithosphere modified by subduction [e.g., Geldmacher et al., 2003]. The subarc mantle wedge can develop high $\mathrm{Lu} / \mathrm{Hf}$, compared to $\mathrm{Sm} /$ $\mathrm{Nd}$, that will evolve over time to high ${ }^{176} \mathrm{Hf} /{ }^{177} \mathrm{Hf}$ relative to ${ }^{143} \mathrm{Nd} /{ }^{144} \mathrm{Nd}$ and displace compositions above the OIB array [e.g., Barry et al., 2006].

[41] The low-titanium basalts have comparable initial $\varepsilon_{\mathrm{Hf}}$ to modern Pacific arcs (and Pacific MORB) with lower initial $\varepsilon_{\mathrm{Nd}}$ (Figure 18) and higher initial ${ }^{87} \mathrm{Sr} /{ }^{86} \mathrm{Sr}$ (Figure 15). The processes in the mantle wedge above a subduction zone can cause a more significant decrease in ${ }^{143} \mathrm{Nd} /{ }^{144} \mathrm{Nd}$ than ${ }^{176} \mathrm{Hf} /{ }^{177} \mathrm{Hf}$, which then evolve along a similar path to depleted compositions well above the mantle array [Kempton et al., 2002; Janney et al., 2005]. Along with high initial $\varepsilon_{\mathrm{Hf}}$, high initial $\mathrm{Sr}$ isotope ratios of the low-titanium basalts indicate involvement of a component derived from an older source with high $\mathrm{Rb} / \mathrm{Sr}$, such as subarc lithospheric mantle. Elemental fractionation in the subarc mantle would lead to radiogenic ${ }^{176} \mathrm{Hf} /{ }^{177} \mathrm{Hf}$ and ${ }^{87} \mathrm{Sr} /{ }^{86} \mathrm{Sr}$ and less radiogenic ${ }^{143} \mathrm{Nd} /{ }^{144} \mathrm{Nd}$ and ${ }^{206} \mathrm{~Pb} /{ }^{204} \mathrm{~Pb}$ [e.g., Janney et al., 2005]; these are the characteristics of the low-titanium basalts.

[42] A binary mixing curve between average $\mathrm{Pa}$ cific arc basalt composition and pelagic sediments, from $\sim 1000 \mathrm{~km}$ east of the Tonga trench (DSDP site 595/596; J. D. Vervoort, personal communication, 2008), in a plot of initial $\varepsilon_{\mathrm{Hf}}$ versus $\varepsilon_{\mathrm{Nd}}$ suggests that involvement of a pelagic sediment component with high $\mathrm{Lu} / \mathrm{Hf}$ could generate high initial Hf isotopic compositions similar to those of the low-titanium basalts (Figure 18). The bulk addition of a pelagic component $(<3 \%)$ that underwent radiogenic ingrowth from high $\mathrm{Lu} / \mathrm{Hf}$ could explain the displacement of low-titanium basalts above the OIB mantle array from a source more depleted than that of the high-titanium basalts. The pelagic sediment component is different than the local contamination of the basal pillowed flows in the Alaska Range that contain sediment filling interpillow voids. Pelagic sediment has very high $\mathrm{Pb}$ contents compared to oceanic basalts, and would be expected to generate different $\mathrm{Pb}$ isotopic compositions in the low- and high-titanium basalts; however, the high- and low-titanium basalts have almost indistinguishable $\mathrm{Pb}$ isotopes. Geldmacher et al. [2003] suggested the high ${ }^{207} \mathrm{~Pb} /{ }^{204} \mathrm{~Pb}$ and ${ }^{208} \mathrm{~Pb} /{ }^{204} \mathrm{~Pb}$ diagnostic of marine sediments may not be apparent in time periods of hundreds of millions of years if relatively high $\mathrm{U}$ and $\mathrm{Pb}$, and high $\mathrm{U} / \mathrm{Pb}$ ratio, in the sediment cause rapid ingrowth of ${ }^{206} \mathrm{~Pb}$ and very little in-growth of ${ }^{207} \mathrm{~Pb}$ and ${ }^{208} \mathrm{~Pb}$ (because of decay of ${ }^{235} \mathrm{U}$ early in Earth's history and the long half-life of ${ }^{232} \mathrm{Th}$ compared to ${ }^{238} \mathrm{U}$ ). The trace element and isotope geochemistry of the low-titanium basalts is best explained by involvement of a subduction-modified mantle component, possibly including a pelagic sediment component, which may have evolved with high ${ }^{176} \mathrm{Hf} /{ }^{177} \mathrm{Hf}$ (and ${ }^{87} \mathrm{Sr} /{ }^{86} \mathrm{Sr}$ ) relative to ${ }^{143} \mathrm{Nd} /{ }^{144} \mathrm{Nd}$.

\section{Conclusions}

[43] The volcanic stratigraphy (3.5-4 km thick) of the Nikolai Formation forms an arcuate belt $\sim 450 \mathrm{~km}$ long in the Wrangell Mountains and Alaska Range (Amphitheater and Clearwater Mountains) in southern Alaska. These sequences formed as part of an extensive oceanic plateau in the Middle to Late Triassic during a single, shortlived phase of volcanism lasting $<5 \mathrm{Ma}$. The Nikolai Formation is bounded by marine sedimentary sequences and uncomformably overlies late Paleozoic volcanic arc sequences. The volcanic stratigraphy is predominantly subaerial flows in Alaska but consists of $\sim 500 \mathrm{~m}$ of submarine flows and basal sills intruding preexisting shale in the southern Alaska Range.

[44] The Nikolai Formation is composed of highand low-titanium basalts that record a change in the source of magmas that constructed the Wrangellia oceanic plateau in Alaska. The low-titanium basalts form the lowest $\sim 400 \mathrm{~m}$ of volcanic stratigraphy in the Alaska Range, and the remainder of the volcanic stratigraphy in the Alaska Range and all of the sampled stratigraphy in the Wrangell Mountains is high-titanium basalt. The geochemistry of erupted sequences of the Wrangellia oceanic plateau in Alaska allows for assessment of the different contributions from the preexisting lithospheric mantle and plume-type mantle. The high-titanium basalts were derived from a uniform plume-type Pacific 


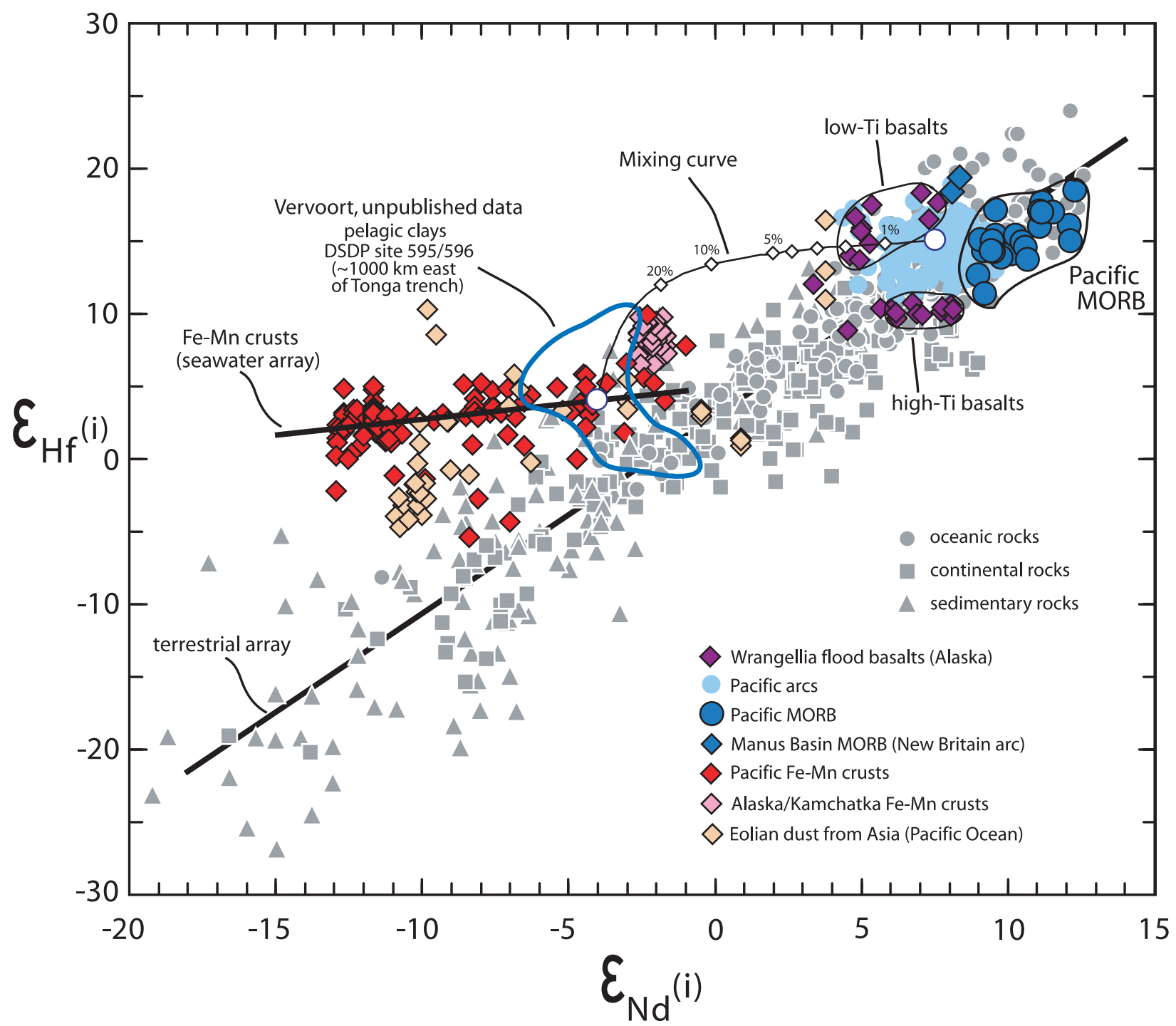

Figure 18. Global Hf-Nd isotope systematics with age-corrected data of the Nikolai Formation in Alaska. Data for terrestrial array are from Vervoort and Blichert-Toft [1999] and references therein. References for data sources for Pacific arcs, Fe-Mn crusts, eolian dust are listed in Auxiliary Material (Text S2). Pelagic sediment data from DSDP $595 / 596$ provided courtesy of J. D. Vervoort (personal communication, 2008). The mixing curve shown is for mixing of pelagic sediment with arc basalt. Average pelagic sediment composition used for mixing curve is initial $\varepsilon_{\mathrm{Hf}}=+5.0$ \pm 4.0 and initial $\varepsilon_{\mathrm{Nd}}=-4.5 \pm 2.4$. Average arc basalt from average of Pearce et al. [2007] and Woodhead et al. [2001]. Pacific MORB from Nowell et al. [1998], Salters and White [1998], and Chauvel and Blichert-Toft [2001].

mantle source, with similar initial $\mathrm{Hf}$ and $\mathrm{Nd}$ isotopic ratios to Ontong Java. The low-titanium basalts involved a HFSE-depleted, high $\varepsilon_{\mathrm{Hf}} \mathrm{com}-$ ponent that is distinct from OIB and MORB and was only involved during the early phase of this major melting event. There is no indication of a transitional lava type in Alaska and the hightitanium basalts do not indicate significant assimilation or interaction of lithospheric material.

[45] Whereas almost all CFBs, and at least one oceanic plateau (e.g., Kerguelen for its Cretaceous part), record involvement of continental lithosphere, Wrangellia flood basalts in Alaska do not indicate involvement of low $\varepsilon_{\mathrm{Nd}}-\mathrm{low} \varepsilon_{\mathrm{Hf}}$ continental material. However, the low-titanium basalts have compositions that indicate melting and/or interaction with subduction-modified lithospheric mantle was involved in their formation. A large thermal anomaly may have initiated melting in the lithospheric mantle due to conduction of heat and possibly a lower liquidus temperature from volatiles in the older subarc lithospheric mantle. The 
lithosphere may have been mechanically or thermally eroded, whereafter melting occurred mostly within the plume to produce the voluminous hightitanium basalts.

\section{Appendix A: Sample Preparation and Analytical Methods}

[46] The least altered samples of the Nikolai Formation were selected for geochemical analysis based on thorough petrographic inspection. Thirty-seven of 68 samples from the Alaska Range and 16 of 36 samples from the Wrangell Mountains were crushed $(400 \mathrm{~g})$ into pieces $<2 \mathrm{~mm}$ in diameter in a Rocklabs hydraulic piston crusher between WC plates. The coarse crush was thoroughly mixed and $100 \mathrm{~g}$ was powdered in a planetary mill using agate jars and balls that were cleaned with quartz sand between samples.

\section{A1. University of Massachusetts XRF Analytical Methods}

[47] Fifty-three sample powders and six duplicate powders were analyzed at the Ronald B. Gilmore X-Ray Fluorescence Laboratory (XRF) at the University of Massachusetts. Major elements were measured on a fused La-bearing lithium borate glass disc using a Siemens MRS-400 spectrometer with a Rh X-ray tube operating at $2700 \mathrm{~W}$. Trace element concentrations ( $\mathrm{Rb}, \mathrm{Sr}, \mathrm{Ba}, \mathrm{Ce}, \mathrm{Nb}, \mathrm{Zr}, \mathrm{Y}$, $\mathrm{Pb}, \mathrm{Zn}, \mathrm{Ga}, \mathrm{Ni}, \mathrm{Cr}, \mathrm{V}$ ) were measured on a separate powder pellet using a Philips PW2400 sequential spectrometer with a $\mathrm{Rh} \mathrm{X}$-ray tube. Loss on ignition (LOI) and ferrous iron measurements were made as described by Rhodes and Vollinger [2004]. Precision and accuracy estimates for the analytical data are described by Rhodes [1996] and Rhodes and Vollinger [2004]. Results for each sample are the average of two separate analyses. A total of four complete duplicates were analyzed for Alaska samples. Eighteen sample duplicate powders of Wrangellia flood basalts were also analyzed at Activation Laboratories and the results for most elements were within analytical error.

\section{A2. PCIGR Trace Element and Isotopic Analytical Methods}

[48] A subset of 24 samples was selected for highprecision trace element analysis and $\mathrm{Sr}, \mathrm{Nd}, \mathrm{Pb}$, and $\mathrm{Hf}$ isotopic analysis at the Pacific Centre for Isotopic and Geochemical Research (PCIGR) at the University of British Columbia (UBC; Table 1). Samples were selected from the 53 samples ana- lyzed by XRF, based on major and trace element chemistry, alteration (low LOI and petrographic alteration index), sample location, and stratigraphic position. Samples were prepared for trace element analysis at the PCIGR by the technique described by Pretorius et al. [2006] on unleached rock powders. Sample powders $(\sim 100 \mathrm{mg})$ were weighed in $7 \mathrm{~mL}$ screw-top Savillex ${ }^{\circledR}$ beakers

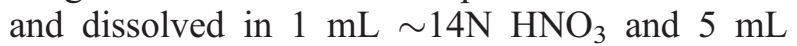
$48 \% \mathrm{HF}$ on a hotplate for $48 \mathrm{~h}$ at $130^{\circ} \mathrm{C}$ with periodic ultrasonication. Samples were dried and redissolved in $6 \mathrm{~mL} 6 \mathrm{~N} \mathrm{HCl}$ on a hotplate for 24 $\mathrm{h}$ and then dried and redissolved in $1 \mathrm{~mL}$ concentrated $\mathrm{HNO}_{3}$ for $24 \mathrm{~h}$ before final drying. Trace element abundances were measured with a Thermo Finnigan Element2 High Resolution-Inductively Coupled Plasma-Mass Spectrometer (HR-ICPMS) following the procedures described by Pretorius et al. [2006] within $24 \mathrm{~h}$ of redissolution. High field strength elements (HFSE) and large ion lithophile elements (LILE) were measured in medium resolution mode at $2000 \mathrm{X}$ dilution using a PFA Teflon spray chamber washed with Aqua Regia for 3 min between samples. Rare earth elements (REE) were measured in high-resolution mode, and $\mathrm{U}$ and $\mathrm{Pb}$ were measured in low-resolution mode, at 2000X dilution using a glass spray chamber washed with $2 \% \mathrm{HNO}_{3}$ between samples. Total procedural blanks and reference materials (BCR-2, BHVO-2) were analyzed with the batch of samples. Indium was used as an internal standard in all samples and standard solutions. Background and standard solutions were analyzed after every five samples to detect memory effects and mass drift.

[49] Sample digestion for purification of $\mathrm{Sr}, \mathrm{Nd}$, $\mathrm{Hf}$, and $\mathrm{Pb}$ for column chemistry involved weighing each sample powder. All samples were initially leached with $6 \mathrm{~N} \mathrm{HCl}$ and placed in an ultrasonic bath for $15 \mathrm{~min}$. Samples were rinsed two times with 18 mega $\Omega-\mathrm{cm} \mathrm{H}_{2} \mathrm{O}$ between each leaching step (15 total) until the supernatant was clear (following the technique of Mahoney [1987], modified by Weis and Frey [1991]). Samples were then dried on a hotplate for $24 \mathrm{~h}$ and weighed again. Sample solutions were then prepared by dissolving $\sim 100-250 \mathrm{mg}$ of the leached powder dissolved in $1 \mathrm{~mL} \sim 14 \mathrm{~N}^{-\mathrm{HNO}_{3}}$ and $10 \mathrm{~mL} 48 \% \mathrm{HF}$ on a hotplate for $48 \mathrm{~h}$ at $130^{\circ} \mathrm{C}$ with periodic ultrasonication. Samples were dried and redissolved in $6 \mathrm{~mL} 6 \mathrm{~N} \mathrm{HCl}$ on a hotplate for $24 \mathrm{~h}$ and then dried. $\mathrm{Pb}$ was separated using anion exchange columns and the discard was used for Sr, REE, and Hf separation. Nd was separated from the REE and Hf required two additional purification steps. Detailed 
procedures for column chemistry for separating Sr, $\mathrm{Nd}$, and $\mathrm{Pb}$ at the PCIGR are described by Weis et al. [2006] and Hf purification is described by Weis et al. [2007]. Sr and $\mathrm{Nd}$ isotope ratios were measured on a Thermo Finnigan Triton Thermal Ionization Mass Spectrometer (TIMS) in static mode with relay matrix rotation on a single $\mathrm{Ta}$ and double Re-Ta filament, respectively. Four to five filaments per barrel of 21 were occupied by standards (NIST SRM 987 for Sr and LaJolla for $\mathrm{Nd)}$ for each barrel where samples were run. Sample $\mathrm{Sr}$ and $\mathrm{Nd}$ isotopic compositions were corrected for mass fractionation using ${ }^{86} \mathrm{Sr} /{ }^{88} \mathrm{Sr}=$ 0.1194 and ${ }^{146} \mathrm{Nd} /{ }^{144} \mathrm{Nd}=0.7219$. Each sample was then normalized using the barrel average of the reference material relative to the values of ${ }^{143} \mathrm{Nd} /{ }^{144} \mathrm{Nd}=0.511858$ and ${ }^{87} \mathrm{Sr} /{ }^{86} \mathrm{Sr}=$ 0.710248 [Weis et al., 2006]. During the period when the Alaska samples were analyzed, the La Jolla $\mathrm{Nd}$ standard gave an average value of $0.511853 \pm 11(\mathrm{n}=8)$ and NIST SRM 987 standard gave an average of $0.710253 \pm 11(n=9 ; 2 \sigma$ error is reported as times $\left.10^{6}\right) .{ }^{147} \mathrm{Sm} /{ }^{144} \mathrm{Nd}$ ratio errors are approximately $\sim 1.5 \%$, or $\sim 0.006$. Leached powder of United States Geological Survey (USGS) reference material BHVO-2 was processed with the samples and yielded $\mathrm{Sr}$ and $\mathrm{Nd}$ isotopic ratios of $0.703473 \pm 8$ and $0.512980 \pm 6$, respectively. These are in agreement with the published values of $0.703479 \pm 20$ and $0.512984 \pm 11$, respectively [Weis et al., 2006]. USGS reference material BCR-2 was processed with the samples and yielded $\mathrm{Sr}$ and $\mathrm{Nd}$ isotopic ratios of $0.705002 \pm 9$ and $0.512633 \pm 7$, respectively, which are in agreement with the published values of $0.705013 \pm 10$ and $0.512637 \pm 12$, respectively [Weis et al., 2006].

[50] $\mathrm{Pb}$ and $\mathrm{Hf}$ isotopic compositions were analyzed by static multicollection on a $\mathrm{Nu}$ Plasma $(\mathrm{Nu}$ Instruments) Multiple Collector-Inductively Coupled Plasma-Mass Spectrometer (MC-ICP-MS). The detailed analytical procedure for $\mathrm{Pb}$ isotopic analyses on the $\mathrm{Nu}$ at the PCIGR is described by Weis et al. [2005]. The configuration for $\mathrm{Pb}$ analyses allows for collection of $\mathrm{Pb}, \mathrm{Tl}$, and $\mathrm{Hg}$ together. $\mathrm{Tl}$ and $\mathrm{Hg}$ are used to monitor instrumental mass discrimination and isobaric overlap, respectively. All sample solutions were analyzed with approximately the same $\mathrm{Pb} / \mathrm{Tl}$ ratio $(\sim 4)$ as the reference material NIST SRM 981. To accomplish this, a small aliquot of each sample solution from the $\mathrm{Pb}$ columns was analyzed on the Ele- ment2 to determine the precise amount of $\mathrm{Pb}$ available for analysis on the $\mathrm{Nu}$ Plasma. The SRM 981 standard was run after every two samples on the $\mathrm{Nu}$ Plasma. During the time samples were run, analyses of the SRM $981 \mathrm{~Pb}$ reference material gave values of ${ }^{206} \mathrm{~Pb} /{ }^{204} \mathrm{~Pb}=$ $16.9403 \pm 19,{ }^{207} \mathrm{~Pb} /{ }^{204} \mathrm{~Pb}=15.4964 \pm 20$, and ${ }^{208} \mathrm{~Pb} /{ }^{204} \mathrm{~Pb}=36.7142 \pm 53(\mathrm{n}=124 ; 2 \sigma$ error is reported as times $10^{4}$ ); these values are in excellent agreement with reported TIMS triple-spike values of Galer and Abouchami [1998]. Results were further corrected by the sample-standard bracketing method or the $\ln$-ln correction method described by White et al. [2000] and Blichert-Toft et al. [2003]. Leached powder of USGS reference material BHVO-2 yielded $\mathrm{Pb}$ isotopic ratios of ${ }^{206} \mathrm{~Pb} /{ }^{204} \mathrm{~Pb}=18.6500 \pm 7,{ }^{207} \mathrm{~Pb} /{ }^{204} \mathrm{~Pb}=$ $15.5294 \pm 7$, and ${ }^{208} \mathrm{~Pb} /{ }^{204} \mathrm{~Pb}=38.2380 \pm 19$. These values are in agreement with leached residues of BHVO-2 from Weis et al. [2006].

[51] Hf isotopic compositions were analyzed following the procedures detailed by Weis et al. [2007]. The configuration for Hf analyses monitored $\mathrm{Lu}$ mass 175 and $\mathrm{Yb}$ mass 172 to allow for interference correction to masses 174 and 176. Hf isotopic ratios were normalized internally for mass fractionation to a ${ }^{179} \mathrm{Hf} /{ }^{177} \mathrm{Hf}$ ratio of $0.7325 \mathrm{using}$ an exponential correction. Standards were run after every two samples and sample results were normalized to the ratio of the in-run daily average and a ${ }^{176} \mathrm{Hf} /{ }^{177} \mathrm{Hf}$ ratio for JMC-475 of 0.282160 . During the course of analyses, the Hf standard JMC-475 gave an average value $0.282153 \pm 3$ $(\mathrm{n}=79)$. USGS reference materials BCR-2 and BHVO-2 were processed with the samples and yielded Hf isotopic ratios of $0.282874 \pm 5$ and $0.283114 \pm 6$, respectively. Published values for BCR-2 and BHVO-2 are 0.282871 \pm 7 and $0.283104 \pm 8$, respectively [Weis et al., 2007].

\section{Acknowledgments}

[52] We are grateful to Jeff Trop and Danny Rosenkrans for their advice on geology and logistics within Wrangell-St. Elias National Park. Jeanine Schmidt was very helpful with field advice and information about Wrangellia geology. We also appreciate insights from Jeff Vervoort and Julian Pearce and thank Nick Arndt for inspiring this study. Bruno Kieffer and Jane Barling assisted with some analytical work. Reviews by Vincent Salters, Andrew Kerr, John Mahoney, and Barry Hanan are greatly appreciated. Funding was provided by NSERC Discovery Grants to J. Scoates and D. Weis. 
A. Greene was supported by a University Graduate Fellowship at UBC.

\section{References}

Armstrong, A. K., and E. M. MacKevett Jr. (1977), The Triassic Chitistone Limestone, Wrangell Mountains, Alaska, U.S. Geol. Surv. Open File Rep., 77-217, D49-D62.

Armstrong, A. K., and E. M. MacKevett Jr. (1982), Stratigraphy and diagenetic history of the lower part of the Triassic Chitistone Limestone, Alaska, U.S. Geol. Surv. Prof. Pap., $1212-A, 1-26$

Arndt, N. T., and U. Christensen (1992), The role of lithospheric mantle in continental flood volcanism: Thermal and geochemical constraints, J. Geophys. Res., 97(B7), 10,967-10,981, doi:10.1029/92JB00564.

Arndt, N. T., G. K. Czamanske, and J. L. Wooden (1993), Mantle and crustal contributions to continental flood volcanism, Tectonophysics, 223, 39-52, doi:10.1016/00401951(93)90156-E.

Barry, T. L., J. A. Pearce, P. T. Leat, I. L. Millar, and A. P. le Roex (2006), Hf isotope evidence for selective mobility of high-field-strength elements in a subduction setting: South Sandwich Islands, Earth Planet. Sci. Lett., 252, 223-244, doi:10.1016/j.eps1.2006.09.034.

Bittenbender, P. E., K. W. Bean, J. M. Kurtak, and J. Deninger Jr. (2007), Mineral assessment of the Delta River Mining District area, East-central Alaska, Tech. Rep. 57, U. S. Bur. of Land Manage., Anchorage, Alaska. (Available at http:// www.blm.gov/pgdata/etc/medialib/blm/ak/aktest/ tr.Par.86412.File.dat/BLM_TR57.pdf)

Blichert-Toft, J., D. Weis, C. Maerschalk, A. Agranier, and F. Albarède (2003), Hawaiian hot spot dynamics as inferred from the $\mathrm{Hf}$ and $\mathrm{Pb}$ isotope evolution of Mauna Kea volcano, Geochem. Geophys. Geosyst., 4(2), 8704, doi:10.1029/ 2002GC000340.

Chauvel, C., and J. Blichert-Toft (2001), A hafnium isotope and trace element perspective on melting of the depleted mantle, Earth Planet. Sci. Lett., 190, 137-151, doi:10.1016/S0012-821X(01)00379-X.

Clift, P., A. Draut, P. Kelemen, J. Blusztajn, and A. Greene (2005), Stratigraphic and geochemical evolution of the Jurassic Talkeetna Volcanic Formation, south-central Alaska, Geol. Soc. Am. Bull., 117(7), 902-925, doi:10.1130/ B25638.1.

Coffin, M. F., R. A. Duncan, O. Eldholm, J. G. Fitton, F. A. Frey, H. C. Larsen, J. J. Mahoney, A. D. Saunders, R. Schlich, and P. J. Wallace (2006), Large igneous provinces and scientific ocean drilling: Status quo and a look ahead, Oceanography, 19(4), 150-160.

Cox, K. G., R. MacDonald, and G. Hornung (1967), Geochemical and petrographic provinces in the Karoo basalts of southern Africa, Am. Mineral., 52, 1451-1474.

d'Acremont, E., S. Leroy, and E. B. Burov (2003), Numerical modelling of a mantle plume: The plume head-lithosphere interaction in the formation of an oceanic large igneous province, Earth Planet. Sci. Lett., 206(3-4), 379-396.

DePaolo, D. J. (1981), Trace element and isotopic effects of combined wallrock assimilation and fractional crystallization, Earth Planet. Sci. Lett., 53, 189-202, doi:10.1016/ 0012-821X(81)90153-9.

Farnetani, C. G., and M. A. Richards (1994), Numerical investigations of the mantle plume initiation model for flood basalt event, J. Geophys. Res., 99, 13,813-13,834, doi:10.1029/94JB00649.
Galer, S. J. G., and W. Abouchami (1998), Practical application of lead triple spiking for correction of instrumental mass discrimination, Mineral. Mag., 62A, 491-492, doi:10.1180/ minmag.1998.62A.1.260.

Gallagher, K., and C. Hawkesworth (1992), Dehydration melting and the generation of continental flood basalts, Nature, 358, 57-59, doi:10.1038/358057a0.

Gardner, M. C., S. C. Bergman, G. W. Cushing, E. M. MacKevett Jr., G. Plafker, R. B. Campbell, C. J. Dodds, W. C. McClelland, and P. A. Mueller (1988), Pennsylvanian pluton stitching of Wrangellia and the Alexander terrane, Wrangell Mountains, Alaska, Geology, 16, 967-971, doi:10.1130/0091-7613(1988)016<0967:PPSOWA >2.3. $\mathrm{CO} ; 2$.

Geldmacher, J., B. B. Hanan, J. Blichert-Toft, K. Harpp, K. Hoernle, F. Hauff, R. Werner, and A. C. Kerr (2003), Hafnium isotopic variations in volcanic rocks from the Caribbean Large Igneous Province and Galapagos hot spot tracks, Geochem. Geophys. Geosyst., 4(7), 1062, doi:10.1029/2002GC000477.

Glen, J. M. G., J. M. Schmidt, and R. Morin (2007), Gravity and magnetic studies of the Talkeetna Mountains, Alaska: Constraints on the geological and tectonic interpretation of southern Alaska, and implications for mineral exploration, in Tectonic Growth of a Collisional Continental Margin: Crustal Evolution of Southern Alaska, edited by K. D. Ridgway et al., Geol. Soc. Am. Spec. Pap., 431, 593-622.

Greene, A. R., S. M. DeBari, P. B. Kelemen, J. Blusztajn, and P. D. Clift (2006), A detailed geochemical study of island arc crust: The Talkeetna Arc section, south-central Alaska, J. Petrol., 47(6), 1051-1093, doi:10.1093/petrology/eg1002.

Greene, A. R., J. S. Scoates, D. Weis, and S. Israel (2008a), Geochemistry of flood basalts from the Yukon (Canada) segment of the accreted Wrangellia oceanic plateau, Lithos, in press.

Greene, A. R., J. S. Scoates, D. Weis, G. T. Nixon, and B. Kieffer (2008b), Magmatic history and growth of the accreted Wrangellia oceanic plateau on Vancouver Island, Canada, J. Petrol, in press.

Hooper, P. R., and C. J. Hawkesworth (1993), Isotopic and geochemical constraints on the origin and evolution of the Columbia River Basalt, J. Petrol., 34(6), 1203-1246.

Hornig, I. (1993), High-Ti and low-Ti tholeiites in the Jurassic Ferrar Group, Antarctica, Geol. Jahrb., Reihe E Geophys., 47, 335-369.

Janney, P. E., A. P. Le Roex, and R. W. Carlson (2005), Hafnium isotope and trace element constraints on the nature of mantle heterogeneity beneath the Central Southwest Indian Ridge $\left(13^{\circ} \mathrm{E}\right.$ to $\left.47^{\circ} \mathrm{E}\right)$, J. Petrol., 46(12), 2427-2464, doi:10.1093/petrology/egi060.

Johnson, M. C., and T. Plank (1999), Dehydration and melting experiments constrain the fate of subducted sediments, Geochem. Geophys. Geosyst., 1(1), 1007, doi:10.1029/ 1999GC000014.

Jones, D. L., N. J. Silberling, and J. Hillhouse (1977), Wrangellia; a displaced terrane in northwestern North America, Can. J. Earth Sci., 14(11), 2565-2577.

Kelemen, P. B., K. T. M. Johnson, R. J. Kinzler, and A. J. Irving (1990), High-field-strength element depletions in arc basalts due to mantle-magma interaction, Nature, 345, 521524, doi:10.1038/345521a0.

Kelemen, P. B., N. Shimizu, and T. Dunn (1993), Relative depletion of niobium in some arc magmas and the continental crust: Partitioning of $\mathrm{K}, \mathrm{Nb}, \mathrm{La}$ and Ce during melt/rock reaction in the upper mantle, Earth Planet. Sci. Lett., 120, 111-134, doi:10.1016/0012-821X(93)90234-Z. 
Kelemen, P. B., K. Hanghøj, and A. R. Greene (2003), One view of the geochemistry of subduction-related magmatic arcs, with emphasis on primitive andesite and lower crust, in The Crust, edited by R. Rudnick, pp. 593-659, Elsevier, Oxford, U. K.

Kempton, P. D., J. A. Pearce, T. L. Barry, J. G. Fitton, C. H. Langmuir, and D. M. Christie (2002), Sr-Nd-Pb-Hf isotope results from ODP Leg 187: Evidence for mantle dynamics of the Australian-Antarctic Discordance and origin of the Indian MORB source, Geochem. Geophys. Geosyst., 3(12), 1074, doi:10.1029/2002GC000320.

Kerr, A. C. (1994), Lithospheric thinning during the evolution of continental large igneous provinces: A case study from the North Atlantic Tertiary province, Geology, 22, 1027-1030, doi:10.1130/0091-7613(1994)022<1027:LTDTEO >2.3. $\mathrm{CO} ; 2$

Kerr, A. C., and J. J. Mahoney (2007), Oceanic plateaus: Problematic plumes, potential paradigms, Chem. Geol., 241, 332-353, doi:10.1016/j.chemgeo.2007.01.019.

Lassiter, J. C. (1995), Geochemical investigations of plumerelated lavas: Constraints on the structure of mantle plumes and the nature of plume/lithosphere interactions, Ph.D. dissertation, 231 pp., Univ. of Calif., Berkeley.

Lassiter, J. C., and D. J. DePaolo (1997), Plume/lithosphere interaction in the generation of continental and oceanic flood basalts: Chemical and isotopic constraints, in Large Igneous Provinces: Continental, Oceanic, and Planetary Flood Volcanism, Geophys. Monogr. Ser., vol. 100, edited by J. J. Mahoney and M. F. Coffin, pp. 335-355, AGU, Washington, D. C.

Lassiter, J. C., D. J. DePaolo, and J. J. Mahoney (1995), Geochemistry of the Wrangellia flood basalt province: Implications for the role of continental and oceanic lithosphere in flood basalt genesis, J. Petrol., 36(4), 983-1009.

MacDonald, G. A., and T. Katsura (1964), Chemical composition of Hawaiian lavas, J. Petrol., 5, 82-133.

MacKevett, E. M., Jr. (1978), Geologic map of the McCarthy Quadrangle, Alaska, U.S. Geol. Surv. Misc. Geol. Invest.Map I-1032, scale 1:250,000.

MacKevett, E. M., Jr., D. P. Cox, R. P. Potter, and M. L. Silberman (1997), Kennecott-type deposits in the Wrangell Mountains, Alaska: High-grade copper ores near a basalt-limestone contact, in Mineral Deposits of Alaska, Econ. Geol. Monogr., vol. 9, edited by R. J. Goldfarb and L. D. Miller, pp. 66-89, Econ. Geol. Publ., Lancaster, Pa.

Mahoney, J. J. (1987), An isotopic survey of Pacific oceanic plateaus: Implications for their nature and origin, in Seamounts, Islands, and Atolls, Geophys. Monogr. Ser., vol. 43, edited by B. H. Keating et al., pp. 207-220, AGU, Washington, D. C.

McDonough, W. F., and S. Sun (1995), The composition of the Earth, Chem. Geol., 120, 223-253, doi:10.1016/00092541(94)00140-4.

Melluso, L., L. Beccaluva, P. Brotzu, A. Gregnanin, A. K. Gupta, L. Morbidelli, and G. Traversa (1995), Constraints on the mantle sources of the Deccan Traps from the petrology and geochemistry of the basalts of Gujarat State (Western India), J. Petrol., 36(5), 1393-1432, doi:10.1093/ petrology/36.5.1393.

Menzies, M. A. (1992), The lower lithosphere as a major source for continental flood basalts: A re-appraisal, in Magmatism and the Causes of Continental Break-up, edited by B. C. Storey, T. Alabaster, and R. J. Pankhurst, Geol. Soc. Spec. Publ., 68, 31-39.

Nobre Silva, I. G., D. Weis, J. Barling, and J. S. Scoates (2008), Leaching systematics for the determination of high- precision $\mathrm{Pb}$ isotope compositions of ocean island basalts, Geochem. Geophys. Geosyst., doi:10.1029/2007GC001891, in press.

Nokleberg, W. J., D. L. Jones, and N. J. Silberling (1985), Origin and tectonic evolution of the Maclaren and Wrangellia terranes, eastern Alaska Range, Alaska, Geol. Soc. Am. Bull., 96, 1251-1270, doi:10.1130/0016-7606(1985) 96<1251:OATEOT $>2.0$. CO;2.

Nokleberg, W. J., J. N. Aleinikoff, J. T. J. Dutro, M. A. Lanphere, N. J. Silberling, S. R. Silva, T. E. Smith, and D. L. Turner (1992), Map, tables, and summary fossil and isotopic age data, Mount Hayes quadrangle, eastern Alaska Range, Alaska, U.S. Geol. Surv. Misc. Field Stud.Map, 1996- $D$, scale. 1:250,000.

Nokleberg, W. J., G. Plafker, and F. H. Wilson (1994), Geology of south-central Alaska, in The Geology of North America, edited by G. Plafker and H. C. Berg, pp. 311-366, Geol. Soc. of Am., Boulder, Colo.

Nomade, S., A. Pouclet, and Y. Chen (2002), The French Guyana doleritic dykes: Geochemical evidence of three populations and new data for the Jurassic Central Atlantic Magmatic Province, J. Geodyn., 34(5), 595-614, doi:10.1016/ S0264-3707(02)00034-0.

Nowell, G. M., P. D. Kempton, S. R. Noble, J. G. Fitton, A. Saunders, J. J. Mahoney, and R. N. Taylor (1998), High precision Hf isotope measurements of MORB and OIB by thermal ionisation mass spectrometry: Insights into the depleted mantle, Chem. Geol., 149, 211-233, doi:10.1016/S0009-2541(98)00036-9.

Patchett, P. J., W. M. White, H. Feldmann, S. Kielinczuk, and A. W. Hofmann (1984), Hafnium/rare earth element fractionation in the sedimentary system and crustal recycling into the Earth's mantle, Earth Planet. Sci. Lett., 69, 365-378, doi:10.1016/0012-821X(84)90195-X.

Pearce, J. A. (1982), Trace element characteristics of lavas from destructive plate boundaries, in Andesites: Orogenic Andesites and Related Rocks, edited by R. S. Thorpe, pp. 526-547, John Wiley, Chichester, U. K.

Pearce, J. A. (2008), Geochemical fingerprinting of oceanic basalts with applications to ophiolite classification and the search for Archean oceanic crust, Lithos, 100, 14-48, doi:10.1016/j.lithos.2007.06.016.

Pearce, J. A., P. D. Kempton, and J. B. Gill (2007), Hf-Nd evidence for the origin and distribution of mantle domains in the SW Pacific, Earth Planet. Sci. Lett., 260, 98-114, doi:10.1016/j.epsl.2007.05.023.

Peate, D. W. (1997), The Parana-Etendeka Province, in Large Igneous Provinces: Continental, Oceanic, and Planetary Flood Volcanism, Geophys. Monogr. Ser, vol. 100, edited by M. F. Coffin and J. Mahoney, pp. 217-245, AGU, Washington, D. C.

Peate, D. W., and C. Hawkesworth (1996), Lithospheric to asthenospheric transition in low-Ti flood basalts from southern Parana, Brazil, Chem. Geol., 127, 1-24, doi:10.1016/ 0009-2541(95)00086-0.

Pik, R., C. Deniel, C. Coulon, G. Yirgu, C. Hofmann, and D. Ayalew (1998), The northwestern Ethiopian Plateau flood basalts: Classification and spatial distribution of magma types, J. Volcanol. Geotherm. Res., 81, 91-111, doi:10.1016/S0377-0273(97)00073-5.

Pik, R., C. Deniel, C. Coulom, G. Yirgu, and B. Marty (1999), Isotopic and trace element signatures of Ethiopian flood basalts: Evidence for plume-lithosphere interaction, Geochim. Cosmochim. Acta, 63, 2263-2279, doi:10.1016/S00167037(99)00141-6. 
Plafker, G., W. J. Nokleberg, and J. S. Lull (1989), Bedrock geology and tectonic evolution of the Wrangellia, Peninsular, and Chugach terranes along the Trans-Alaskan Crustal Transect in the northern Chugach Mountains and southern Copper River basin, Alaska, J. Geophys. Res., 94, 42554295, doi:10.1029/JB094iB04p04255.

Plafker, G., J. C. Moore, and G. R. Winkler (1994), Geology of the southern Alaska margin, in The Geology of North America, edited by G. Plafker and H. C. Berg, pp. 389-449, Geol. Soc. of Am., Bouler, Colo.

Pretorius, W., D. Weis, G. Williams, D. Hanano, B. Kieffer, and J. S. Scoates (2006), Complete trace elemental characterization of granitoid (USGSG-2,GSP-2) reference materials by high resolution inductively coupled plasma-mass spectrometry, Geostand. Geoanal. Res., 30(1), 39-54, doi:10.1111/ j.1751-908X.2006.tb00910.x.

Rhodes, J. M. (1996), Geochemical stratigraphy of lava flows sampled by the Hawaii Scientific Drilling Project, J. Geophys. Res., 101(B5), 11,729-11,746, doi:10.1029/ 95JB03704.

Rhodes, J. M., and M. J. Vollinger (2004), Composition of basaltic lavas sampled by phase-2 of the Hawaii Scientific Drilling Project: Geochemical stratigraphy and magma types, Geochem. Geophys. Geosyst., 5, Q03G13, doi:10.1029/ 2002GC000434.

Richards, M. A., D. L. Jones, R. A. Duncan, and D. J. DePaolo (1991), A mantle plume initiation model for the Wrangellia flood basalt and other oceanic plateaus, Science, 254, 263267, doi:10.1126/science.254.5029.263.

Richter, D. H., J. G. Smith, M. A. Lanphere, G. B. Dalrymphe, B. L. Reed, and N. Shew (1990), Age and progression of volcanism, Wrangell volcanic field, Alaska, Bull. Volcanol., 53, 29-44, doi:10.1007/BF00680318.

Rioux, M., B. Hacker, J. Mattinson, P. Kelemen, J. Blusztajn, and G. Gehrels (2007), Magmatic development of an intraoceanic arc: High-precision U-Pb zircon and whole-rock isotopic analyses from the accreted Talkeetna arc, south-central Alaska, Geol. Soc. Am. Bull., 119, 1168-1184, doi:10.1130/ B25964.1.

Salters, V. J. M., and A. Stracke (2004), Composition of the depleted mantle, Geochem. Geophys. Geosyst., 5, Q05B07, doi:10.1029/2003GC000597.

Salters, V. J., and W. White (1998), Hf isotope constraints on mantle evolution, Chem. Geol., 145, 447-460, doi:10.1016/ S0009-2541(97)00154-X.

Salters, V. J. M., and A. Zindler (1995), Extreme ${ }^{176} \mathrm{Hf} /{ }^{177} \mathrm{Hf}$ in the sub-oceanic mantle, Earth Planet. Sci. Lett., 129, $13-$ 30, doi:10.1016/0012-821X(94)00234-P.

Salters, V., J. Blichert-Toft, Z. Fekiacova, A. Sachi-Kocher, and M. Bizimis (2006), Isotope and trace element evidence for depleted lithosphere in the source of enriched Ko'olau basalts, Contrib. Mineral. Petrol., 151(3), 297-312, doi:10.1007/s00410-005-0059-y.

Saltus, R. W., T. Hudson, and F. H. Wilson (2007), The geophysical character of southern Alaska: Implications for crustal evolution, in Tectonic Growth of a Collisional Continental Margin: Crustal Evolution of Southern Alaska, edited by K. D. Ridgeway et al., Geol. Soc. Am. Spec. Pap., 431, 1-20.

Saunders, A. D. (2005), Large igneous provinces: Origin and environmental consequences, Elements, 1, 259-263, doi:10.2113/gselements.1.5.259.

Saunders, A. D., M. Storey, R. W. Kent, and M. J. Norry (1992), Consequences of plume-lithosphere interactions, in Magmatism and the Causes of Continental Breakup, edited by B. C. Storey, T. Alabaster, and R. J. Pankhurst, Geol. Soc. London Spec. Publ., 68, 41-60.
Schmidt, J. M., and R. K. Rogers (2007), Metallogeny of the Nikolai large igneous province (LIP) in southern Alaska and its influence on the mineral potential of the Talkeetna Mountains, in Tectonic Growth of a Collisional Continental Margin: Crustal Evolution of Southern Alaska, edited by K. D. Ridgway et al., Geol. Soc. Am. Spec. Pap., 431, 623-648.

Smith, J. G., and E. M. MacKevett Jr. (1970), The Skolai Group in the McCarthy B-4, C-4, C-5 Quadrangles, Wrangell Mountains, Alaska, U.S. Geol. Surv. Bull., 1274-Q, Q1-Q26.

Smith, T. E. (1981), Geology of the Clearwater Mountains, south central Alaska, Geol. Rep. 60, 72 pp., Alaska Div. of Geol. and Geophys. Surv., Fairbanks, Alaska.

Stout, J. H. (1976), Geology of the Eureka Creek area, eastcentral Alaska Range, Geol. Rep. 46, 32 pp., Alaska Div. of Geol. and Geophys. Surv., Fairbanks.

Thompson, P. M. E., P. D. Kempton, and A. C. Kerr (2008), Evaluation of the effects of alteration and leaching on Sm-Nd and Lu-Hf systematics in submarine mafic rocks, Lithos, 104, 164-176, doi:10.1016/j.lithos.2007.12.005.

Turner, S., C. Hawkesworth, K. Gallagher, K. Stewart, D. Peate, and M. Mantovani (1996), Mantle plumes, flood basalts, and thermal models for melt generation beneath continents: Assessment of a conductive heating model and application to the Paraná, J. Geophys. Res., 101(B5), 11,503-11,518, doi:10.1029/96JB00430.

van de Flierdt, T., M. Frank, D.-C. Lee, A. N. Halliday, B. C. Reynolds, and J. R. Hein (2004), New constraints on the sources and behavior of neodymium and hafnium in seawater from Pacific Ocean ferromanganese crusts, Geochim. Cosmochim. Acta, 68(19), 3827-3843, doi:10.1016/ j.gca.2004.03.009.

Vervoort, J. D., and J. Blichert-Toft (1999), Evolution of the depleted mantle: Hf isotope evidence from juvenile rocks through time, Geochim. Cosmochim. Acta, 63, 533-556, doi:10.1016/S0016-7037(98)00274-9.

Vervoort, J. D., P. J. Patchett, J. Blichert-Toft, and F. Albarède (1999), Relationships between Lu-Hf and Sm-Nd isotopic systems in the global sedimentary system, Earth Planet. Sci. Lett., 168, 79-99, doi:10.1016/S0012-821X(99)00047-3.

Vervoort, J. D., P. J. Patchett, F. Albarède, J. Blichert-Toft, R. L. Rudnick, and H. Downes (2000), Hf-Nd isotopic evolution of the lower crust, Earth Planet. Sci. Lett., 181, 115-129, doi:10.1016/S0012-821X(00)00170-9.

Weis, D., and F. A. Frey (1991), Isotope geochemistry of the Ninetyeast Ridge basement basalts: $\mathrm{Sr}, \mathrm{Nd}$, and $\mathrm{Pb}$ evidence for involvement of the Kerguelen hot spot, in Proceedings of the Ocean Drilling Program, Scientific Results, edited by J. Weissel et al., pp. 591-610, Ocean Drill. Program, College Station, Tex.

Weis, D., B. Kieffer, C. Maerschalk, W. Pretorius, and J. Barling (2005), High-precision $\mathrm{Pb}-\mathrm{Sr}-\mathrm{Nd}-\mathrm{Hf}$ isotopic characterization of USGS BHVO-1 and BHVO-2 reference materials, Geochem. Geophys. Geosyst., 6, Q02002, doi:10.1029/ 2004GC000852.

Weis, D., et al. (2006), High-precision isotopic characterization of USGS reference materials by TIMS and MC-ICP-MS, Geochem. Geophys. Geosyst., 7, Q08006, doi:10.1029/ 2006GC001283.

Weis, D., B. Kieffer, D. Hanano, I. N. Silva, J. Barling, W. Pretorius, C. Maerschalk, and N. Mattielli (2007), Hf isotope compositions of U.S. Geological Survey reference materials, Geochem. Geophys. Geosyst., 8, Q06006, doi:10.1029/ 2006GC001473.

White, R. S., and D. McKenzie (1995), Mantle plumes and flood basalts, J. Geophys. Res., 100, 17,543-17,585, doi:10.1029/95JB01585. 
White, W. M., F. Albarède, and P. Télouk (2000), Highprecision analysis of $\mathrm{Pb}$ isotope ratios by multi-collector ICP-MS, Chem. Geol., 167, 257-270, doi:10.1016/S00092541(99)00182-5.

Wilson, F. H., J. D. Dover, D. C. Bradley, F. R. Weber, T. K. Bundtzen, and P. J. Haeussler (1998), Geologic map of Central (Interior) Alaska, U.S. Geol. Surv. Open File Rep., 98-133-A. (Available at http://wrgis.wr.usgs.gov/open-file/of98-133-a/)

Wilson, F. H., K. A. Labay, N. B. Shew, C. C. Preller, S. Mohadjer, and D. H. Richter (2005), Digital Data for the Geology of Wrangell-Saint Elias National Park and Preserve, Alaska, U.S. Geol. Surv. Open File Rep., 2005-1342. (Available at http://pubs.usgs.gov/of/2005/1342/)

Wooden, J. L., G. K. Czamanske, V. A. Fedorenko, N. T. Arndt, C. Chauvel, R. M. Bouse, B. S. W. King, R. J.
Knight, and D. F. Siems (1993), Isotopic and trace-element constraints on mantle and crustal contributions to Siberian continental flood basalts, Noril'sk area, Siberia, Geochim. Cosmochim. Acta, 57, 3677-3704, doi:10.1016/00167037(93)90149-Q.

Woodhead, J. D., J. M. Hergt, J. P. Davidson, and S. M. Eggins (2001), Hafnium isotope evidence for 'conservative' element mobility during subduction zone processes, Earth Planet. Sci. Lett., 192, 331-346, doi:10.1016/S0012-821X(01) 00453-8.

Xu, Y., S. L. Chung, B.-M. Jahn, and G. Wu (2001), Petrologic and geochemical constraints on the petrogenesis of PermianTriassic Emeishan flood basalts in southwestern China, Lithos, 58, 145-168, doi:10.1016/S0024-4937(01)00055-X. 